\title{
Paleoceanographic evolution of the Gulf of Tehuantepec (Mexican Pacific) during the last $\sim 6$ millennia
}

\author{
Ángela García-Gallardo, ' (D) María Luisa Machain-Castillo' \\ and Laura Almaraz-Ruiz ${ }^{2}$
}

\begin{abstract}
Oceanographic dynamics in the Gulf of Tehuantepec (GT) are the direct consequence of climate variability, mainly influenced by the strong wind regime locally called "Tehuanos" and the interactions between the Intertropical Convergence Zone (ITCZ) and El Niño Southern Oscillation (ENSO). The area is characterized by intense upwelling driven by the Tehuanos within one of the largest Oxygen Minimum Zones (OMZ) in the world. Upwelling carries nutrient-rich subsurface waters to the surface and provides marine resources to the coasts conforming one of the main economic sectors in the region. In this study, sediment core MD02-252I is used to perform the first high-resolution paleoceanographic reconstruction of the last 6 millennia in the GT. The main focus is put on the analysis of the benthic foraminifera (BF) assemblages inhabiting within the OMZ, which appear to respond to bottom oxygenation and climate variations of the last $\sim 6000$ years. The microfossil assemblages throughout the sediment core revealed, first, intervals where the lack of foraminifera provide evidence of episodes of strong deoxygenation that triggered the dissolution of calcareous foraminiferal tests, second, a longterm decline of bottom-water oxygenation in the last $\sim 2500$ years likely responding to the southward migration of the ITCZ. Last, variations in response to the transitions between cold and warm periods occurred during the last 2-2.5 millennia and cyclicities of I470years resembling Bond Cycles suggest a climatic connection between the Pacific and Atlantic Oceans during the late-Holocene.
\end{abstract}

\section{Keywords}

benthic foraminifera, bottom dissolved oxygen, Gulf of Tehuantepec, Late-Holocene Climate, Oxygen Minimum Zone, upwelling

Received 17 June 2020; revised manuscript accepted 16 October 2020

\section{Introduction}

Climate dynamics of the Tropical Pacific Ocean is the result of intricate interactions between ocean and atmosphere. The atmospheric pressure differences across the eastern and western Pacific coasts causes precipitation and trade wind flow patterns that modulate ocean superficial temperature and current flows. The intensity of the winds fluctuates according to the interannual variability of the El Niño Southern Oscillation (ENSO), which is in turn modulated by the relative position of the Intertropical Convergence Zone (ITCZ), producing more intense winds when the ITCZ is at its southernmost position (Clarke, 1988; Hurd, 1929; Molina-Cruz and Martínez-López, 1994; Metcalfe et al., 2015; Schneider et al., 2014; Staines-Urías et al., 2015). The Gulf of Tehuantepec (GT), located in the Tropical Mexican Pacific between $14^{\circ} 30^{\prime} \mathrm{N}$ to $16^{\circ} 12^{\prime} \mathrm{N}$ and $92^{\circ} 00^{\prime} \mathrm{W}$ to $96^{\circ} 00^{\prime} \mathrm{W}$ (Figure 1), is directly affected by these climatic processes. Its continental shelf occupies an extension of $200 \mathrm{~km}$ and $200 \mathrm{~m}$ water depth, extending until $\sim 1000 \mathrm{~m}$ in the continental slope (CarranzaEdwards et al., 1998; Lavín et al., 1992; Vásquez-Bedoya et al., 2008). This portion of the eastern Pacific Ocean is bathed by different water masses along the water column. At the surface, the California and Costa Rica Counter Current meet from their northern and southern origins. Below are the highly saline Subtropical Subsurface and the Intermediate Water (Wyrtki, 1966). In the GT, the trade-wind regime locally called "Tehuanos" is favored by the orography of the Sierra Madre mountain range on the Isthmus of
Tehuantepec, causing the winds to reach up to $100 \mathrm{~km} / \mathrm{h}$ (Figure 1, Romero-Centeno et al., 2003). This powerful wind regime is responsible for the development of upwelling in the area, which is quite intense in the GT during the Holocene (Arellano-Torres et al., 2013). Upwelling triggers high rates of primary productivity of up to $350 \mathrm{gC} / \mathrm{m}^{2}$ year in the surface (Antoine et al., 1996). As a consequence, large amounts of organic matter (OM) sink and degrade causing oxygen consumption and depletion in the water column. In addition, poor water mixing in the GT, and the presence of the old, nutrient-rich, and oxygen-poor intermediate waters in the Pacific derived from the North Atlantic Deep Water after its path through the Atlantic (Sarmiento et al., 1988; Sen Gupta and Machain-Castillo, 1993; Tsuchiya and Talley, 1998) have favored the development of one of the largest Oxygen

\footnotetext{
'Unidad Académica de Procesos Oceánicos y Costeros, Instituto de Ciencias del Mar y Limnología, Universidad Nacional Autónoma de México, Mexico

${ }^{2}$ Posgrado en Ciencias del Mar y Limnología, Universidad Nacional Autónoma de México, Mexico

\section{Corresponding author:}

Ángela García-Gallardo, Unidad Académica de Procesos Oceánicos y Costeros, Instituto de Ciencias del Mar y Limnología, Universidad Nacional Autónoma de México, Circuito Exterior s/n, Ciudad Universitaria, Mexico City 045 I0, Mexico.

Email: garcia.gallardo.angela@gmail.com
} 


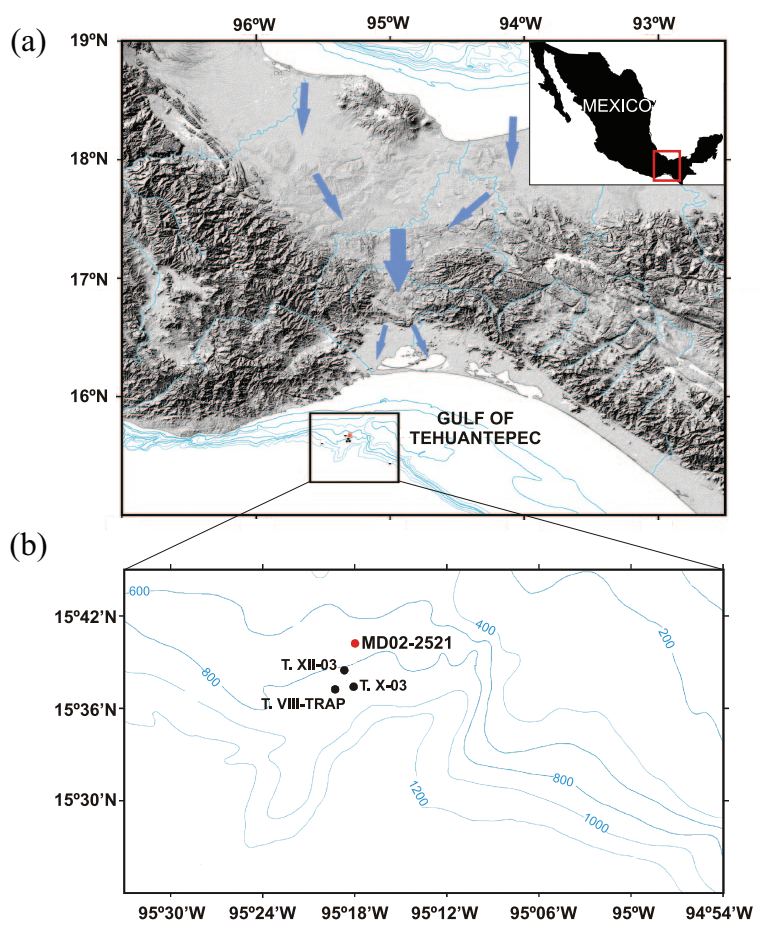

Figure I. (a) Map of the Isthmus and Gulf of Tehuantepec. Blue arrows show the direction of the "Tehuano" winds. (b) Detailed bathymetry map of the study area. The red point shows the location of sediment core MD02-2521. Black points display the location of the stations from where oxygen and CTD data were collected (Table 3).

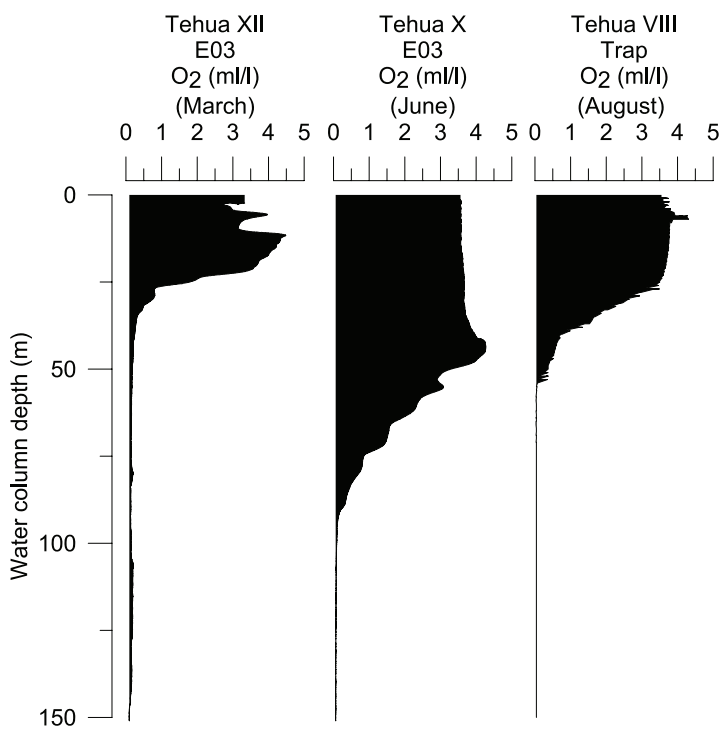

Figure 2. Profiles of dissolved oxygen (DO) in the water column until $150 \mathrm{~m}$ depth compiled from oceanographic campaigns Tehua VIII, Tehua X, and Tehua XII (Table 3). DO values until $800 \mathrm{~m}$ depth are in Supplemental Appendix I.

Minimum Zones (OMZ) in the world besides those in the Eastern Tropical South Pacific, the Arabian Sea, the Bay of Bengal, and off southwest Africa (Kamykowski and Zentara, 1990). The OMZ in the GT lies between 50-100 and $>800 \mathrm{~m}$ depth with values of dissolved oxygen (DO) between 0.03 and $0.05 \mathrm{ml} / 1$ (Figure 2; Supplemental Appendix 1), eventually reaching full anoxia (or $0.0 \mathrm{ml} / \mathrm{l}$ ) (Cline and Richards, 1972; Pérez-Cruz and MachainCastillo, 1990). Changes of upwelling intensity bring in turn consequent variations in column stratification, productivity, and more or less availability and/or reachability of nutrients and OM to the seafloor (Davies et al., 2011; Ortiz et al., 2004).

From a socio-economic point of view, large rates of productivity are crucial for the development of fisheries (Fiedler and Lavín, 2017), which are an important part of the economic growth in this region, being the GT situated at the southern boundary of the Mexican Exclusive Economic Zone. However, global warming is most likely going to dramatically modify ocean dynamics, thus affecting these productivity patterns. Additionally, it is thought that anthropogenic impact is affecting the area due to pollution by oil-derived hydrocarbon and heavy metals, herbicides, and insecticides (Ruiz-Fernández et al., 2004, 2009; Tapia-García, 1998).

Despite the large interest that the GT represents from climatic, oceanographic, and socioeconomic points of view, only a handful of studies have focused on this area, especially as far as paleoceanography is concerned. This study is a paleoceanographic reconstruction in the GT using benthic foraminifera $(\mathrm{BF})$ as a proxy for the evolution of bottom-water oxygen conditions. The huge diversity of these calcareous protozoans primarily responds to DO and OM fluxes reaching the seabed and have been successfully used in sedimentary records as proxies for changes in upwelling and bottom oxygenation in OMZ's (e.g. Altenbach et al., 1999; Balestra et al., 2018; Bernhard and Reimers, 1991; Hermelin, 1991; Jorissen et al., 1995; Murray, 2006; Ohkushi et al., 2013; Pérez-Cruz and Machain-Castillo, 1990; Shibahara et al., 2007). Although low oxygen conditions may cause decreasing richness and diversity of foraminiferal populations and even dissolution of their tests (Schnitker et al., 1980; Wignall and Myers, 2015), other studies demonstrate that BF can remain abundant under extreme environments (e.g. hydrocarbon seeps, Sen Gupta et al., 2009). In particular, within OMZ's, limited availability of oxygen levels reduce the BF population to a few dominant species with adapted morphologic attributes, such as little size and large pores to facilitate gas exchange which allow them to tolerate strong oxygen deficiencies such as anoxia (Sen Gupta and Machain-Castillo, 1993; Sen Gupta et al., 2009). The populations are nearly completely composed of calcareous taxa since agglutinated species are less tolerant to hypoxic conditions, while some miliolids may occur during episodes of rapid ventilation (Bernhard and Sen Gupta, 1999; Den Dulk et al., 2000; Gooday and Rathburn, 1999; Gooday, 2003).

The present study contributes new micropaleontological data from sediment core MD02-2521 with the aim to provide the first reconstruction of the evolution of bottom-water conditions and climate implications in the GT across the past 6 millennia.

\section{Materials and methods}

\section{Sediment sampling}

This study is focused on the $571.5 \mathrm{~cm}$ long sediment core MD022521 retrieved on the west coast of the GT $\left(15^{\circ} 40.25^{\prime} \mathrm{N}\right.$; $95^{\circ} 18.00^{\prime} \mathrm{W}$, Figure 1). The operation was carried out using a Calypso Square Corer at $718.7 \mathrm{~m}$ depth during the IMAGES VII/ MD126 MONA "Margins of North America" Cruise on June 17th, 2002 aboard the RV "Marion Dufresne" (Beaufort, 2002). Sediment core MD02-2521 is mainly composed by olive green to grayish silty-clay containing diatoms, nannofossils, foraminifers, sponge spicules, and OM (Beaufort, 2002). Laminations are well preserved and are distributed intermittently throughout the sedimentary sequence (see Figure 3).

Bulk sediment samples of approximately $5 \mathrm{~cm}^{3}$ were collected from every $5 \mathrm{~cm}$ at the Laboratory of Micropaleontology of the Institute of Marine Sciences and Limnology (National Autonomous University of Mexico). Wet samples were weighed, dried, sieved through a $63 \mu \mathrm{m}$ sieve using tap water, dried at room temperature in Whatman ${ }^{\mathrm{TM}}$ filter papers, and weighed 

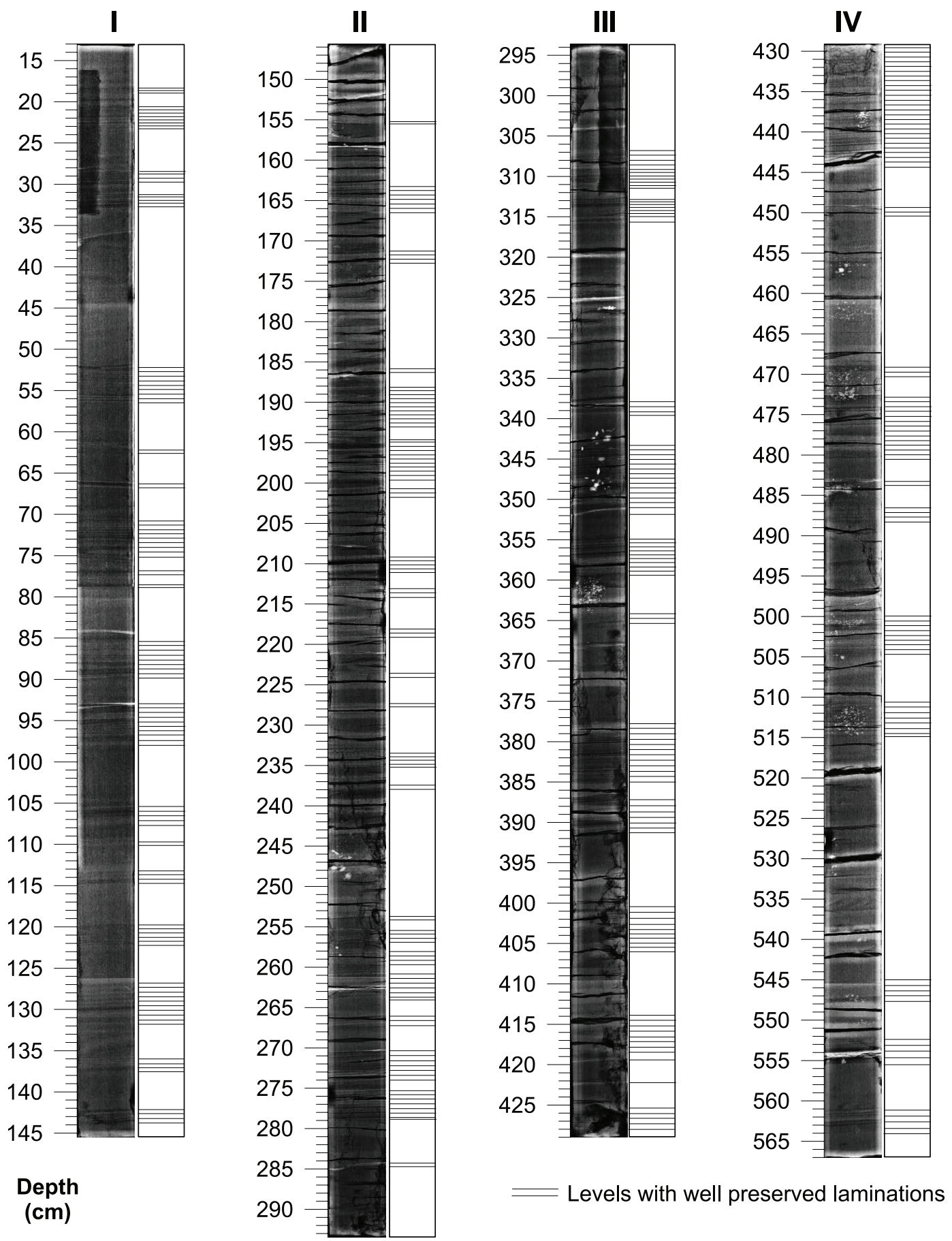

Figure 3. X-ray photographs of the four sections in which sediment core MD02-252I was divided. A sketch at the right side of each photograph clarifies the levels where laminations are well preserved.

again. Sediment samples at $141 \mathrm{~cm}$ and $556 \mathrm{~cm}$ were not available because they were previously sampled for dating.

\section{Radiocarbon $\left({ }^{14} \mathrm{C}\right)$ dating}

The chronology of sediment core MD02-2521 was established by the assignment of eight control points at levels $0.1-0.6,9-10$, $100-100.5,192.5-193,300-300.5,399.5-400,500-500.5,556-$ $556.5 \mathrm{~cm}$ depth (Supplemental Appendix 2, Figure 4). The ages of bulk marine sediment samples were determined by radiocarbon $\left({ }^{14} \mathrm{C}\right)$ dating with an Accelerator Mass Spectrometry (AMS) at the Lalonde AMS Laboratory (Ottawa, Canada). Radiocarbon ages were calibrated to calendar years before present (cal yrs BP) with the Marine13 radiocarbon age calibration curve (Reimer et al., 2013) using the Calib 7.1 software (Stuiver et al., 2017), and corrected for the constant surface reservoir age of $456 \pm 51$ years obtained from a shell of Turritella leverostoma in Huatulco Bay (Oaxaca, Mexico; Berger et al., 1966). Ages between control points were calculated by linear interpolation assuming constant sedimentation rate between dated levels.

\section{Micropaleontological analyses}

A total of 112 samples representing $0.5 \mathrm{~cm}$ thick layers were analyzed every $5 \mathrm{~cm}$ from core depths $11.0-566.5 \mathrm{~cm}$ for micropaleontological purposes. A minimum of 300 specimens of BF was picked and identified from each sample (Phleger, 1954). Of the total, sediment at two levels (141-141.5 and 556-556.5 cm) was not available at the time of sampling, nine samples did not contain BF, and 14 samples contained less than 300 specimens (Supplemental Appendix 3). Large samples were fractionated until obtaining an aliquot of 300 specimens, later considering the 


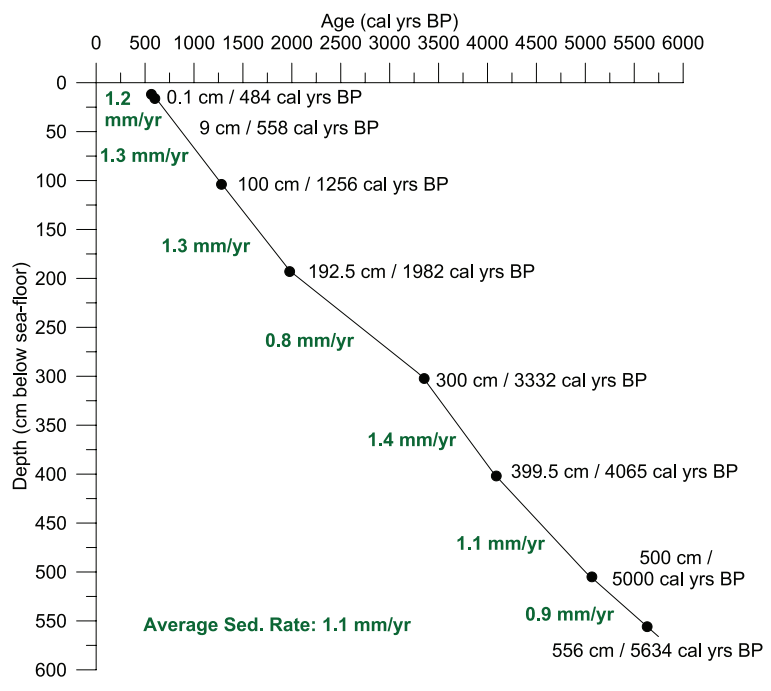

Figure 4. Age model of sediment core MD02-252I. Determined ages are indicated next to their corresponding control points and calculated sedimentation rates between control points are shown. The intervals of uncertainty $(2 \sigma 95 \%)$ for each calibrated date is found in Supplemental Appendix 2.

number of splits to calculate the total number of foraminifera per gram and relative abundances (Supplemental Appendices 3 and 4; Figures 5 and 6). Total numbers of planktonic foraminifera were counted in the samples. An Olympus SZ6045 stereomicroscope and a JEOL JSM-6360LV Scanning Electron Microscope (SEM) were used for identification and documentation of BF. SEM pictures of the main taxa are shown in Figure 7a.

Additionally, relative abundances of living rose bengal stained Bolivinella seminuda and Episominella sandiegoensis in superficial samples from the GT were compiled from previous campaigns (Tehua II and Tehua XII) aboard the RV "El Puma" including depth and DO levels (Table 1) for data comparison.

\section{Multivariate statistics}

In order to assess the evolution of foraminiferal assemblages throughout the studied period, a multivariate statistical analysis was performed over the data matrix using the PAST (Paleontological Statistics, version 3.22) software, specifically designed for paleontological analyses (Hammer and Harper, 2006). To improve statistics, the data matrix was simplified by removing rare species that add noise (see Supplemental Appendix 3 for details on the simplifying procedure). Finally, 93 samples predominated by eight taxa (see Figure $6 ; 9.3 \%$ of the total fauna) were included in the analysis. A Q-mode cluster analysis running the UPGMA (Unweighted Pair Group Method using Arithmetic averages) algorithm and Bray-Curtis similarity index were performed to group samples according to their similarities in foraminiferal composition (Figure 8a, Hammer et al., 2001; Hammer and Harper, 2006). Dominance $\left(\lambda=\Sigma p_{\mathrm{i}}^{2}\right.$; where $p_{\mathrm{i}}=n_{\mathrm{i}} / n$ or the proportion of species i) and diversity (Simpson: $1-\lambda=1-\Sigma p_{\mathrm{i}}^{2}$ ) indices were computed using the bootstrap procedure (Hammer et al., 2001; Hammer and Harper, 2006; Figure 5, Supplemental Appendix 4). A SIMPER (Similarity Percentage) analysis was performed for each simplified dataset where all samples were pooled using the Bray-Curtis similarity (Table 2). The SIMPER analysis allows for the identification of the taxa responsible for the observed differences between the obtained groups of samples (Clarke, 1993). A Principal Component Analysis (PCA) was computed running the variance-covariance matrix to identify the number of components or environmental factors causing the sample clustering (Figure 8b, Supplemental Appendix 5).

The data were subjected to linear $r$ (Pearson) correlation analysis (Hammer and Harper, 2006) to figure out the positive or negative correspondence between taxa abundance, dominance, and diversity indices (Supplemental Appendix 6).

\section{Dissolved oxygen}

Oxygen values across the water column were compiled from different oceanographic campaigns during the years 2010, 2012, and 2014 aboard the RV "El Puma" in the GT (Figure 1) by a CTD (Conductivity, Temperature, Depth; model SBE 9 Plus by Seabird Scientific) device (Table 3, Supplemental Appendix 1). Stations were chosen according to their proximity to sediment core MD022521 to assess the variability of the local OMZ (Figure 2).

\section{Spectral analysis}

In order to find out cyclic patterns in the foraminiferal record, a time series (spectral) analysis was carried out with the "Astrochron" R package (version 0.9, Meyers et al., 2019) on the dominance record. Data were interpolated and detrended before creating the periodogram.

\section{Results}

\section{Dissolved oxygen in the Gulf of Tehuantepec}

Column water DO profiles (Supplemental Appendix 1) were obtained from the three campaigns described in the Material and Methods section (Table 3, Figures 1 and 2). Maximum values, ranging from 4.27 to $4.48 \mathrm{ml} / 1$, are followed by a pronounced fall that culminates in values from 0.03 to $0.05 \mathrm{ml} / 1$ (Supplemental Appendix 1) corresponding to the position of their respective oxyclines. Dissolved oxygen profiles show that the OMZ upper limit is $\sim 50-100 \mathrm{~m}$ depth within the water column, depending on the position of the thermocline and the season in which oxygen values were measured (Figure 2, Supplemental Appendix 1). At the end of the winter season (March), upwelling and high productivity rates cause water mixing and shallower DO depletion $(\sim 50-70 \mathrm{~m})$ in contrast to summer months (June and August) when the lack of upwelling and warmer waters causes the depletion at larger depth $(\sim 100 \mathrm{~m}$; Figure 2$)$. DO profiles measured in June show, in addition, lower values at the surface that might be caused by higher precipitation rates, runoff, and temperatures due to the position of the ITCZ over the GT (Figure 2). Minimum values are maintained throughout the water column until $>800 \mathrm{~m}$ depth (Figure 2, Supplemental Appendix 1).

Table I. Compilation of dissolved oxygen $(\mathrm{ml} / \mathrm{l})$, depth $(\mathrm{m})$, and relative abundance $(\%)$ of $B$. seminuda and E. sandiegoensis from campaigns Tehua II and Tehua XII in the GT.

\begin{tabular}{llllll}
\hline Campaign (month/year) & Station & DO $(\mathrm{ml} / \mathrm{l})$ & Water depth $(\mathrm{m})$ & B. seminuda $(\%)$ & E. sandiegoensis $(\%)$ \\
\hline Tehua II October 2004 & E-18 & 0.11 & 283.0 & 50.63 & - \\
Tehua II October 2004 & E-32a & 0.13 & 198.0 & 79.15 & - \\
Tehua XII March 2014 & E-03 & 0.06 & 743.7 & 7.72 & 15.06 \\
Tehua XII March 20I4 & E-0I & 0.05 & 747.0 & 5.42 & 33.13 \\
\hline
\end{tabular}


Table 2. Contribution of the main species in each cluster according to the Similarity Percentage (SIMPER) analysis carried out on the $10 \%$ cut-off level matrix.

\begin{tabular}{|c|c|c|c|c|c|}
\hline Taxon & Contribution (\%) & Cumulative (\%) & Cluster I & Cluster 2 & Sample $2 \mathrm{I}-2 \mathrm{I} .5$ \\
\hline E. sandiegoensis & 29.6 & 29.6 & 45.4 & 23.5 & 5.8 \\
\hline B. seminuda & 21.0 & 50.6 & 11.1 & 26.8 & 2.7 \\
\hline T. delicata & 12.7 & 63.4 & 12.2 & 2.9 & 5.8 \\
\hline B. tenuata & 12.1 & 75.4 & 11.1 & 7.6 & 76.3 \\
\hline E. obesa & 8.5 & 84.0 & 4.5 & 10.0 & 3.1 \\
\hline G. nitidula & 6.7 & 90.1 & 1.3 & 5.9 & 0.0 \\
\hline Epistominella sp. & 5.8 & 96.6 & 2.1 & 5.9 & 0.0 \\
\hline P. bradyana & 3.4 & 100.0 & 3.3 & 3.7 & 0.0 \\
\hline
\end{tabular}

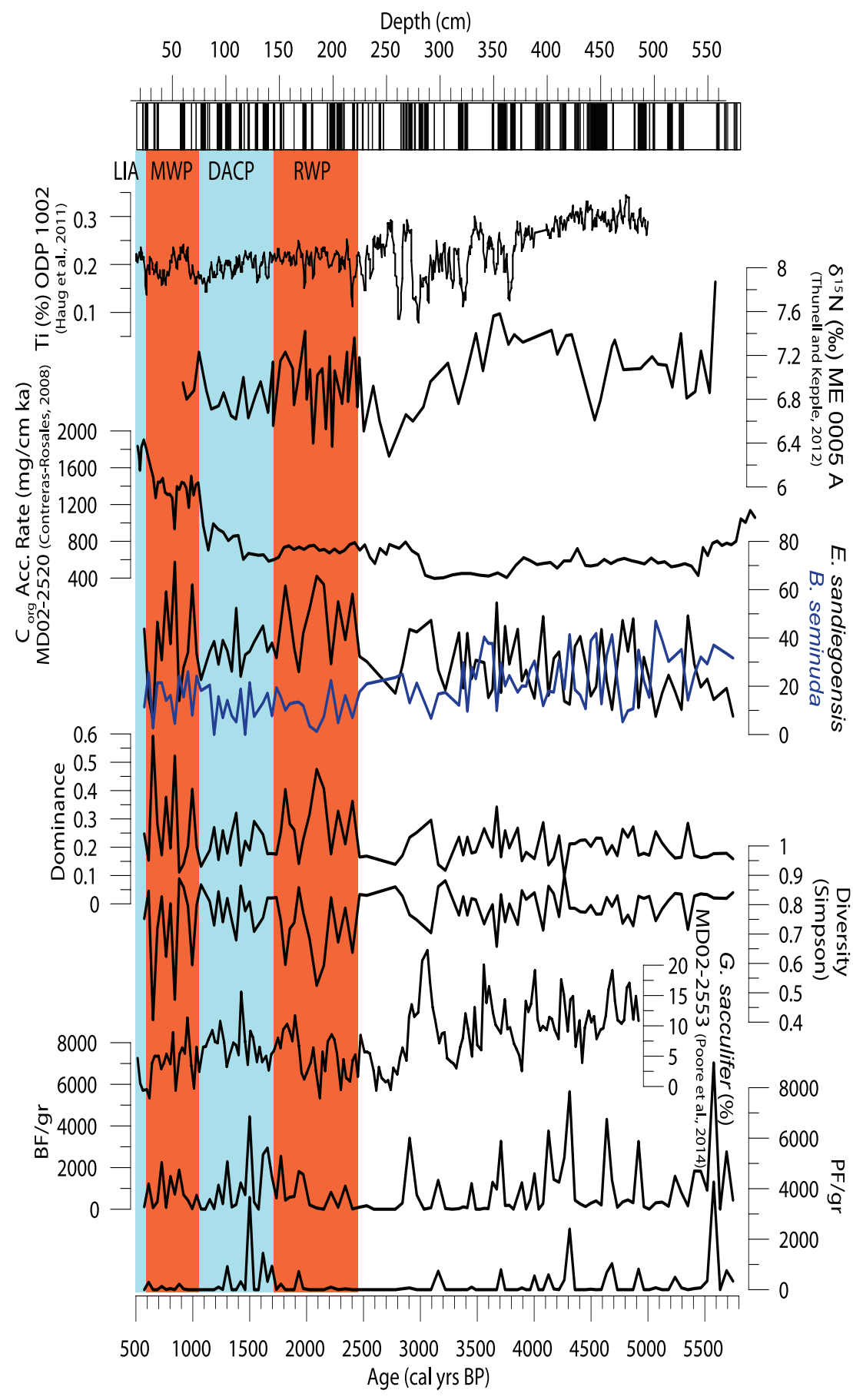

Figure 5. Records of the calculated benthic foraminifera (BF) and planktonic foraminifera (PF) per gram, the diversity index, the dominance index, and abundance records of the taxa $E$. sandiegoensis and $B$. humilis, represented against the laminations sketch with the corresponding depth of sediment core MD02-252I (this study). Samples lacking BF were deleted to improve visualization and comparison between records. Data from previous studies have been used for comparison: $\delta^{15} \mathrm{~N}$ (core ME0005A) from Thunell and Kepple (2002); titanium (ODP Site 1002) from Haug et al. (200I), the abundance of G. sacculifer (core MD02-2553) from Poore et al. (2004), and $C_{\text {org }}$ (core MD02-2520) from Contreras-Rosales (2008). The succession of blue and orange areas corresponds to cold and warm periods: the Roman Warm Period (RWP), the Dark Ages Cold Period (DACP), the Medieval Warm Period (MWP), and the Little Ice Age (LIA). 
Table 3. Dissolved oxygen data of the water column in the Gulf of Tehuantepec compiled from campaigns Tehua VIII, Tehua X, and Tehua XII. Campaign ID, time of sampling, station ID, location, and station depth are displayed.

\begin{tabular}{lllll}
\hline Campaign month/year & Station & Latitude $(\mathrm{N})$ & Longitude $(\mathrm{W})$ & Depth $(\mathrm{m})$ \\
\hline Tehua VIII August 2010 & Trap & $15^{\circ} 37.00^{\prime}$ & $95^{\circ} 19.00^{\prime}$ & 738.7 \\
Tehua X June 2012 & E-03 & $15^{\circ} 37.43^{\prime}$ & $95^{\circ} 18.07^{\prime}$ & 876 \\
Tehua XII March 2014 & E-03 & $15^{\circ} 40.42^{\prime}$ & $95^{\circ} 19.93^{\prime}$ & 749 \\
\hline
\end{tabular}

\section{Age-depth model, sedimentation rates, and spectral analysis of sediment core MD02-252I}

The age-depth model performed over core MD02-2521 dates the last level to 5634 cal yrs BP (Supplemental Appendix 2). According to the ages determined for each dated level, a quasi-constant sedimentation rate is apparent in Figure 4 with an average value of $1.1 \mathrm{~mm} /$ year. This result is consistent with the parallel sediment core MD02-2520, with an average sedimentation rate of $1 \mathrm{~mm} /$ year (Blanchet et al., 2012). However, it varies between dated levels showing the lowest value $(0.8 \mathrm{~mm} /$ year $)$ between 3332 and 1982 cal yrs BP immediately preceded by the highest rate $(1.4 \mathrm{~mm} / \mathrm{year})$ between 4065 and $3332 \mathrm{cal}$ yrs BP (Supplemental Appendix 2, Figure 4). In accordance with these sedimentation rates, the average temporal resolution between samples is 47 years (Supplemental Appendix 3). Uncertainties intervals for each dated level are recorded in Supplemental Appendix 2. The $\sim 6-\mathrm{m}$ long sediment core MD02-2521 show well-preserved laminations throughout the entire sedimentary sequence. However, laminations are not continuous but they occur in short or longer heterogeneous intervals across the core (Figure 3).

The periodogram obtained from the spectral analysis (Asthrochron R package) after interpolation and detrending the dominance record reveals six main frequencies of 0.000676 , $0.000773,0.001256,0.001353,0.003382$, and 0.003672 year $^{-1}$ corresponding to cycles with periodicities of 1470, 1294, 796, 739, 296, and 272 years, respectively.

\section{Dominance and diversity}

The dominance index record reveals two main trends that split the sedimentary sequence into two parts at around $2591 \mathrm{cal}$ yrs BP (Figure 5). Larger dominance with maximum values of 0.4-0.6 is noticeable in the recent part, while the oldest section shows lower values with maxima reaching $0.2-0.3$ (Figure 5). Dominance maxima correspond to the highest peaks of E. sandiegoensis as evidenced by a high correlation between these parameters $(0.65$; see Figure 5; Supplemental Appendix 6). The diversity index shows very similar records with opposed peaks to that of dominance (Figure 5) as determined by their strong negative correlation (-1; Supplemental Appendix 6). In this case, minimum spikes go down from 0.6 to 0.7 along the oldest section, to $0.4-0.6$ in the uppermost period (Figure 5). This varying trend at both sides of the 2500 cal yrs BP point is not as evident in the curves of $\mathrm{BF} / \mathrm{gr}$ and $\mathrm{PF} / \mathrm{gr}$, although periods with higher numbers of individuals per gram are noticeable at some points or periods (e.g., 5691, 5578, 5011-4312, 3708, 2905, and 1499; Figure 5).

\section{Q-mode cluster analysis and resulting benthic foraminiferal assemblages}

The Q-mode cluster analysis performed on the abundance matrix including species present in samples with $10 \%$ abundance in at least one sample (cophenetic correlation coefficient: 0.73 ) divides the 93 samples into two groups of taxa according to their similarity $(\%)$ in foraminiferal composition and one spare sample after applying a cutting line at the similarity level of 0.6 (Figure 8a).
The SIMPER analysis revealed the taxa responsible for the difference between groups, according to their abundance in each sample (Table 2). Epistominella sandiegoensis accounts for almost a third $(29.6 \%)$ which, together with $B$. seminuda $(21.0 \%)$, contribute around $50 \%$ of the total assemblage (Table 2). Cluster 1 is characterized by the highest contribution of the abundance of $E$. sandiegoensis accounting for almost half (45.4\%); the rest of the taxa contribute percentages of $\leqslant 12.2 \%$ (Table 2). Cluster 2 is formed by a similar contribution of $B$. seminuda $(26.8 \%)$ and $E$. sandiegoensis $(23.5 \%)$, and low contributions of the other taxa ( $\leqslant 10.0 \%)$. Sample $21-21.5$ was separated from the clusters due to its extremely high percentage of Buliminella tenuata $(76.3 \%)$ compared to the low contribution of the other taxa $(\leqslant 5.8 \%)$.

A thorough discussion about taxonomic and ecological issues on E. sandiegoensis and B. seminuda contrasting data from recent (Table 1) and fossil (core MD02-2521) specimens is presented in the Discussion section.

\section{Principal component analysis}

The PCA reveals that $58.76 \%$ of the overall variance is expressed by $\mathrm{PC} 1$, which is quite significant when contrasted with $\mathrm{PC} 2$ and PC3 that explain $19.65 \%$ and $9.68 \%$, respectively (Supplemental Appendix 5). The rest of the components do not appear to be significant according to the scree plot (Figure 8b). Regarding the species contributing to each $\mathrm{PC}, \mathrm{PC} 1$ shows a strong positive contribution of E. sandiegoensis (0.77) followed by Takayanagia delicata (0.24). In the opposite direction, the strongest influence is exerted by $B$. seminuda ( -0.55$)$. In PC2, the largest contribution corresponds to $B$. tenuata $(0.84)$ opposing $E$. sandiegoensis $(-0.39)$ and B. seminuda $(-0.27)$ (Supplemental Appendix 5).

\section{Discussion}

\section{Benthic foraminifera within the $O M Z$ in sediment core MD02-252 I: Taxonomic and ecological notes}

The total foraminiferal population found in the last 6000 years in core MD02-2521 is composed of 86 taxa (Supplemental Appendix 3) containing eight taxa (Figure 6) accounting for $9.3 \%$ of the total fauna. The 78 remaining species occur rarely and/or in very low percentages in the samples without affecting the main outcome, as statistical analyses demonstrated that results stay identical by cutting the abundance matrix at the $0.5 \%, 1 \%, 3 \%, 5 \%$, and $10 \%$ levels (see Supplemental Appendix 3 for details).

The eight most abundant foraminiferal taxa recovered in sediment core MD02-2521 have been reported from very poorly oxygenated settings. Epistominella sandiegoensis was reported in environments with DO levels between 0.5 and $3.0 \mathrm{ml} / 1 \mathrm{DO}$ in the Gulf of California (Douglas and Heitman, 1979; Golik and Phleger, 1977). Takayanagia delicata was encountered in the gulfs of California and Panama under different DO concentrations ranging from $<0.3$ to $2.0 \mathrm{ml} / 1$ (Bandy, 1961; Blake, 1976; Douglas and Heitman, 1979; Golik and Phleger, 1977) and it was present in the Kimki Ridge offshore southern California as low oxygen species close to the seep area (McGann and Conrad, 2018). From the taxa herein reported, B. tenuata seems to be the most tolerant species to low DO concentrations since it can endure 


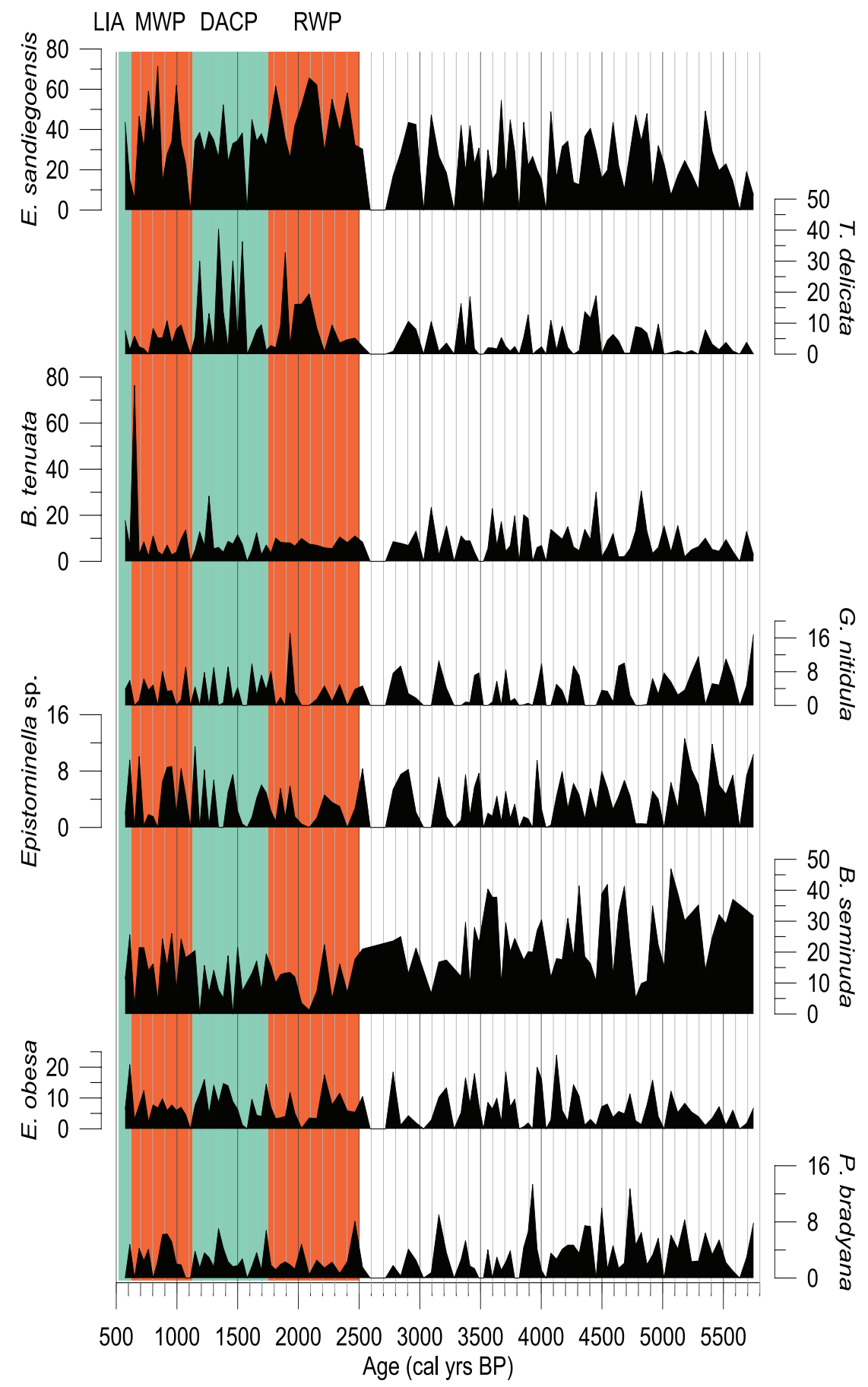

Figure 6. Relative abundance records of the eight most abundant BF taxa in sediment core MD02-252I. The succession of red and blue areas corresponds to warm and cold periods: the Roman Warm Period (RWP), the Dark Ages Cold Period (DACP), the Medieval Warm Period (MWP), and the Little Ice Age (LIA).

complete anoxia $(0.0 \mathrm{ml} / 1$, Bernhard et al., 1997; Ohkushi et al., 2013), although other studies have encountered this species at more diverse DO levels ranging from 0.05 to $0.8 \mathrm{ml} / 1$ in the Gulf of California as well (Bernhard et al., 1997; Blake, 1976; Douglas and Heitman, 1979; Harman, 1964; Quintero and Gardner, 1987; Páez et al., 2001). Bolivinella seminuda has been reported in variable concentrations along the west coast of North America, from the Santa Barbara basin to the GT with values ranging from 0.03 to $0.1 \mathrm{ml} / 1$ (Bandy, 1961; Bernhard et al., 1997; Harman, 1964; Pérez-Cruz and Machain-Castillo, 1990; Phleger and Soutar, 1973). Pseudoparrella bradyana was found in the GT under $0.3 \mathrm{ml} / 1$ to $0.1 \mathrm{ml} / 1$ (Pérez-Cruz and Machain-Castillo, 1990; Vásquez-Bedoya et al., 2008). Regarding Epistominella obesa,
Smith (1964) reported its occurrence in Central America and El Salvador at 0.4 and $0.3 \mathrm{ml} / 1$, respectively, as well as Gyroidina nitidula, found only in El Salvador at ranges of about $0.3 \mathrm{ml} / 1$.

Epistominella sandiegoensis: taxonomic and ecological notes. Since E. sandiegoensis is the most abundant species (E. sandiegoensis-dominance correlation coefficient: 0.65, Supplemental Appendix 6) in core MD02-2521, it deserves a more detailed assessment of its biology and oxygen tolerance ranges. Species of the genus Epistominella have been reported from environments with different oxygenation levels. While Cannariato et al. (1999) associated the genus to well-oxygenated environments, species such as Epistominella exigua have been encountered under 


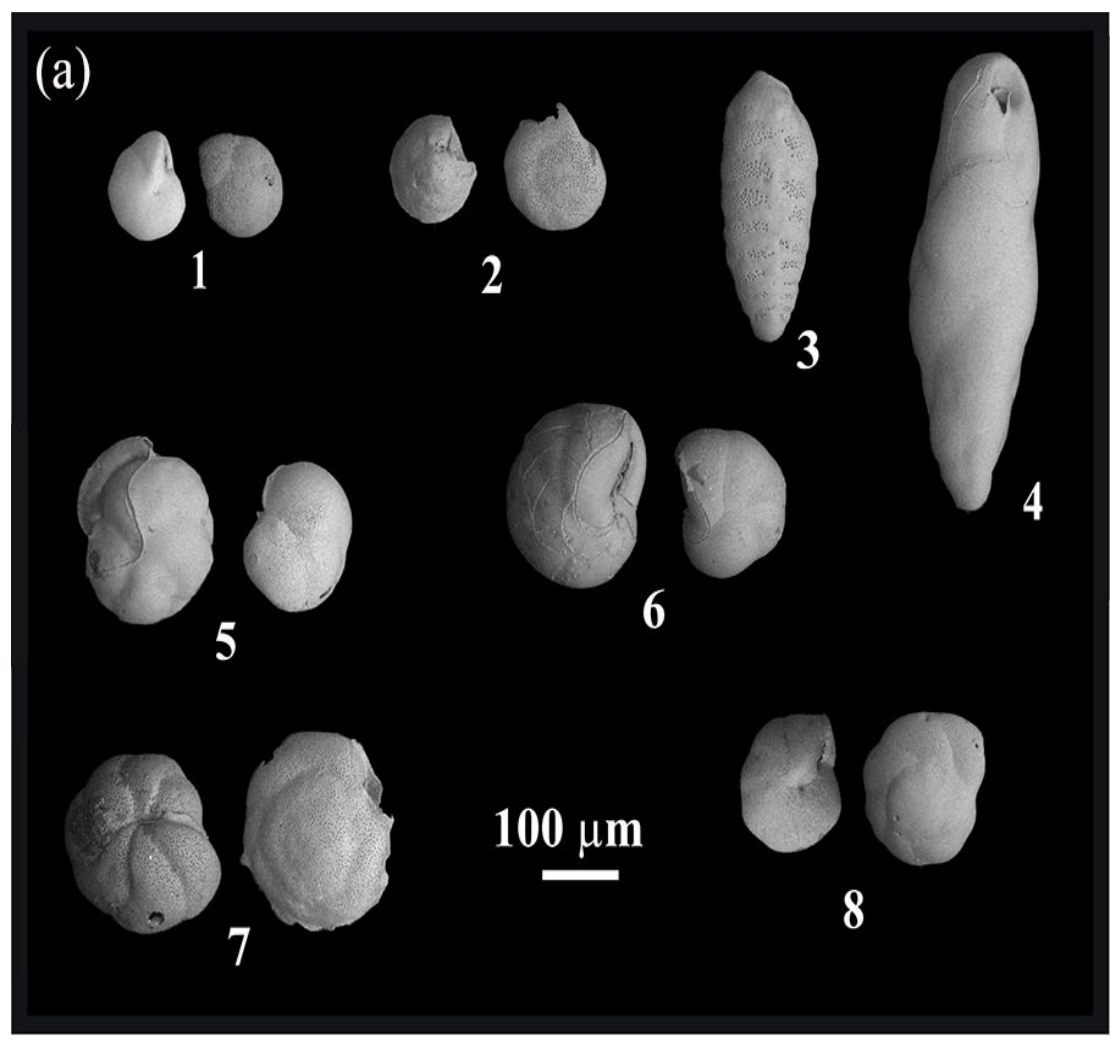

(b)

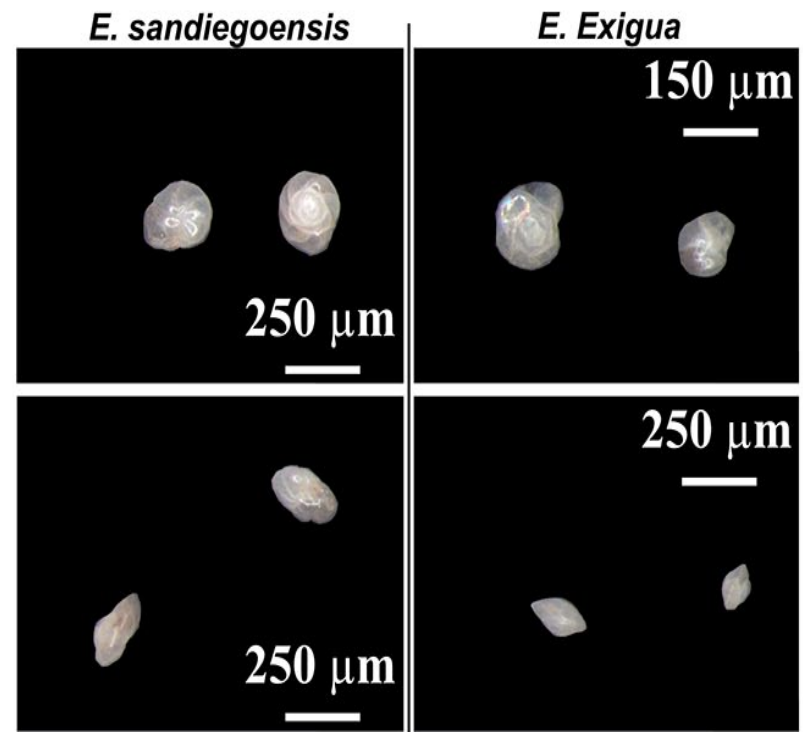

Figure 7. (a) Scanning Electron Microscope (SEM) images of the eight most abundant benthic foraminiferal taxa in sediment core MD02252I. (I) Epistominella sandiegoensis, (2) Epistominella sp., (3) Bolivinella seminuda, (4) Buliminella tenuata, (5) Takayanagia delicata, (6) Epistominella obesa, (7) Gyroidina nitidula, and (8) Pseudoparrella bradyana. Scale bar: $100 \mu \mathrm{m}$. (b) Stereomicroscope images of Epistominella sandiegoensis and Epistominella exigua.

reducing environments $\left(\mathrm{H}_{2} \mathrm{~S}\right)$ within bacterial (Beggiatoa) mats (Lobegeier and Sen Gupta, 2008) and bathyal hydrocarbon seeps in the Gulf of Mexico (Sen Gupta et al., 2009). Smith (1964) considers that E. exigua and E. sandiegoensis are synonyms. However, despite both taxa do present similar morphological features, some differences can be detected from the original species descriptions (E. sandiegoensis in Uchio, 1960; E. exigua originally Pulvinulinella exigua in Brady, 1884). The most noticeable is related to the periphery (lobular for E. exigua, rounded for $E$. sandiegoensis), the number of chambers in the last whorl (five in E. exigua, six in E. sandiegoensis), and the sutures (generally depressed in E. sandiegoensis while in E. exigua they are depressed only in the umbilicus area). To make sure of this determination, well-preserved specimens of each species from the Gulf of Mexico (SGM9 campaign; for details, see MachainCastillo et al., 2019) and the GT (Tehua II) were compared to each other and our MD02-2521 specimens, detecting the mentioned differences amongst both taxa (Figure 7b); therefore we consider them to be different species.

In terms of ecological requirements, E. sandiegoensis has been reported in settings with DO levels between 0.5 and $3.0 \mathrm{ml} / 1$ DO in the Gulf of California (Douglas and Heitman, 1979; Golik and Phleger, 1977). This would put this taxon, amongst the common low oxygen taxa, within the category of less tolerant to low oxygen levels, agreeing with Cannariato et al. (1999) about the genus Epistominella. Living specimens of E. sandiegoensis from 
(a)

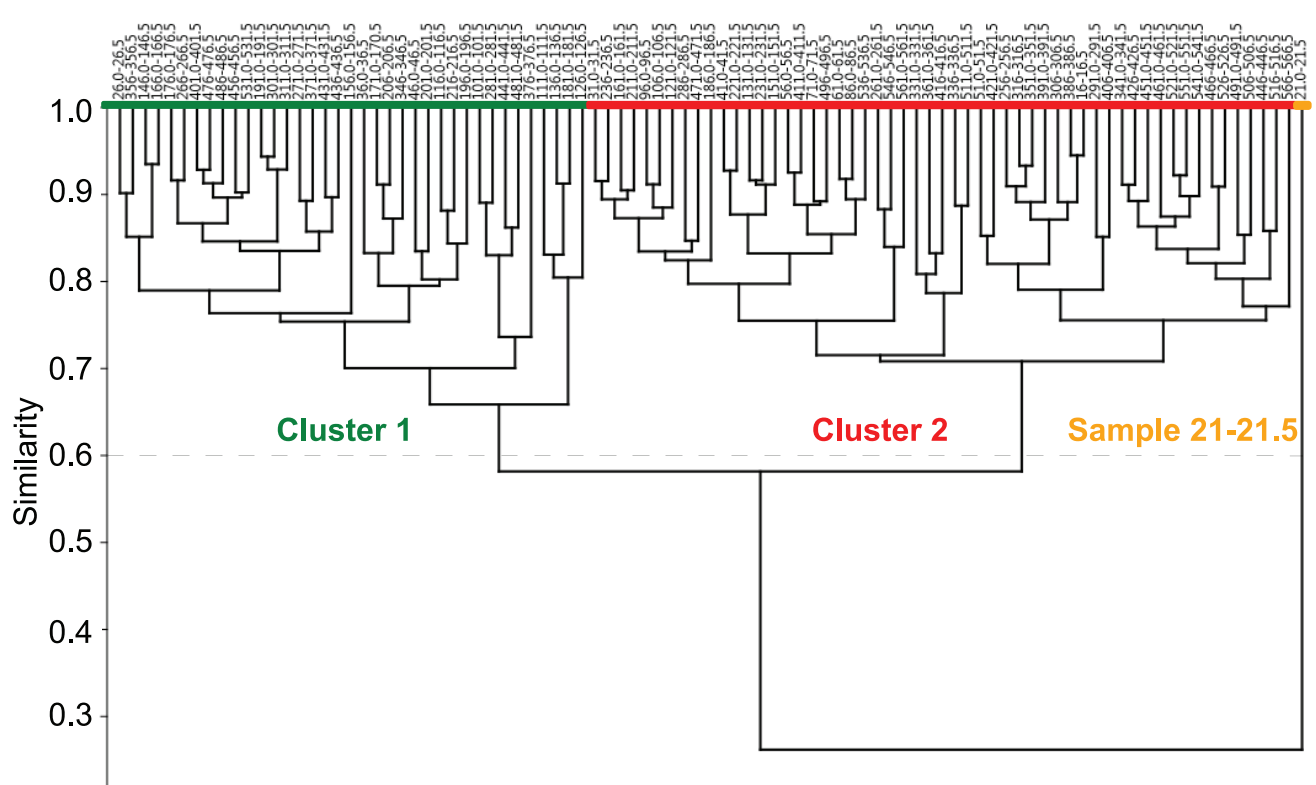

0.2

(b)

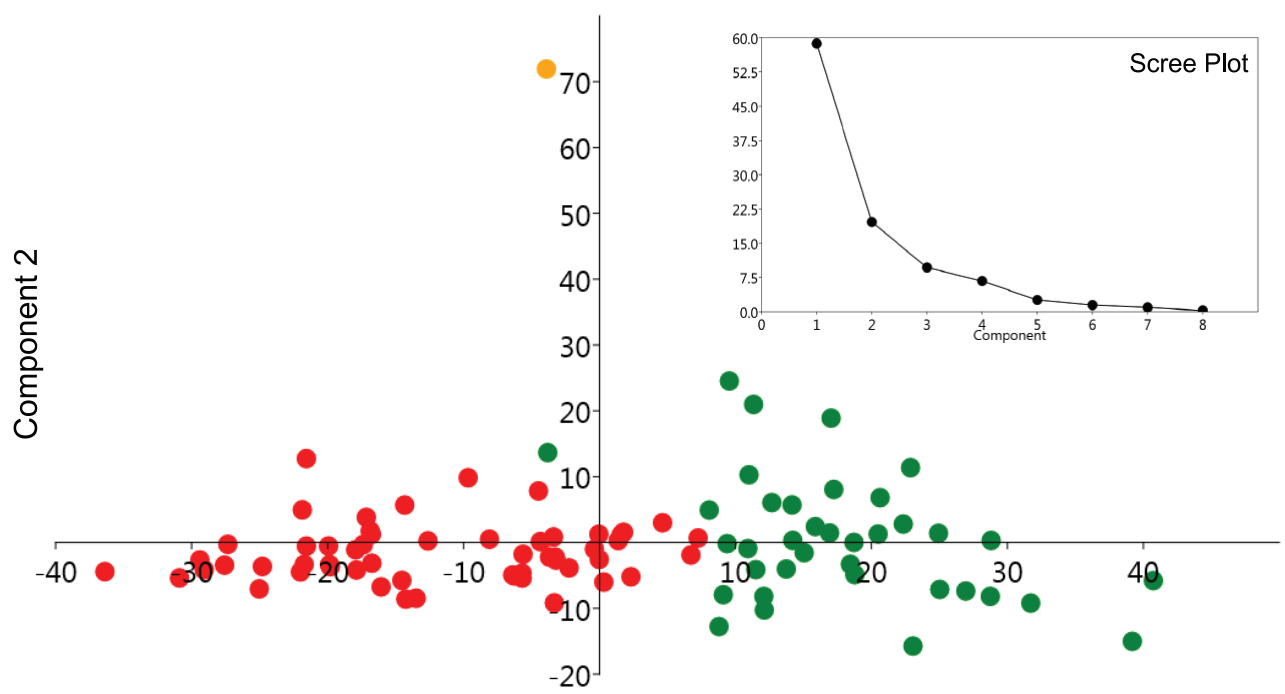

Component 1

Figure 8. (a) Q-mode cluster analysis (UPGMA, Bray Curtis similarity index; correlation: 0.73 ) of sediment samples from sediment core MD02-252I. The analysis was run on the data matrix containing taxa occurring $>10 \%$ in at least one sample. The cut at the similarity level of 0.6 (dashed line) groups the samples into two clusters and one separated sample in accordance with their foraminiferal composition. (b) Principal Component I versus Principal Component 2 and scree plot as the result of the Principal Component Analysis run on the data matrix containing taxa occurring $>10 \%$ in at least one sample. Colors correspond to clusters in (a).

the Tehua XII campaign at depths around $740 \mathrm{~m}$ in the GT are abundant within DO levels of $0.05-0.06 \mathrm{ml} / 1$ in contrast to shallower samples $(198,283 \mathrm{~m}$ depth) with higher DO levels $(0.13$, $0.11 \mathrm{ml} / 1$, respectively) where no specimens of E. sandiegoensis were found (Table 1). These data reveal that this taxon seems to prefer deeper habitats with low oxygenation in the GT. For these reasons, in contrast to the values reported in the literature, it appears that E. sandiegoensis is one of the most tolerant species to low-oxygen levels in the GT, thus it will be used in this study as an indicator of such conditions.

Bolivinella seminuda: Taxonomic and ecological notes. In this study, an initial attempt to separate Bolivinella humilis and $B$. seminuda was done. Bolivinella humilis was originally categorized as a variety of B. seminuda (Bolivina seminuda var. humilis by Cushman \& McCulloch, 1942, according to marinespecies.com). However, the original classification is no longer accepted, instead, it is considered as a differentiated species under the name Bolivinella humilis (Cushman \& McCulloch, 1942). This is supported by Smith (1963) who stated that due to the lack of gradation between both taxa, $B$. humilis and $B$. seminuda are different species. However, the descriptions of the respective taxa do not show substantial differences in Smith (1963). Despite different morphological attributes were specified (e.g. B. seminuda is larger and has a subcylindrical cross-section while $B$. humilis was described as smaller with oval cross-section), the rest of the description for $B$. seminuda is actually true for $B$. humilis, and vice versa, according to the images in Smith (1963, Plate 29). On 
the other hand, despite being able to discern amongst slightly different outlines, specimens in sediment core MD02-2521 do not allow an accurate morphological diagnosis since preservation does not permit so. In most cases, first chambers are missing, and assessing subcylindrical or oval cross-section may be too subjective and little accurate in this case. The rest of the features in the description (such as clear imperforate areas on all or some of its chambers, sutures oblique in the periphery, and chambers increasing as added; Smith, 1963) are fulfilled by $B$. seminuda specimens in MD02-2521, thus $B$. seminuda and specimens resembling $B$. humilis were lumped in B. seminuda.

As mentioned above, B. seminuda was found within a large range of DO $(0.03-0.1 \mathrm{ml} / 1)$ along the Pacific coast from North America (Bandy, 1961; Bernhard et al., 1997; Harman, 1964; Phleger and Soutar, 1973; Pérez-Cruz and Machain-Castillo, 1990). This range is very similar to that found in the GT, where living specimens of this taxon occur in samples from the platform (283 and $198 \mathrm{~m}$ depth) to the slope (743.7 and $747 \mathrm{~m}$ depth at DO levels of $0.11-0.05 \mathrm{ml} / \mathrm{l}$; Table 1 ). However, the abundance of this taxon, in contrast to that of E. sandiegoensis, seems to decrease with depth in the GT since relative abundances of up to $50.63 \%$ and $79.15 \%$ were found in the platform at DO levels of 0.11 and $0.13 \mathrm{ml} / 1$, respectively, while percentages of 7.72 and $5.42 \%$ occur in the slope at DO values of 0.06 and $0.05 \mathrm{ml} / 1$, respectively (Table 1). For this reason, this study considers $B$. seminuda less tolerant to low-oxygen concentrations in the slope of the GT, thus an indicator of higher oxygen conditions in core MD02-2521.

\section{Bottom-water environment characterization across the last 6000 years in the GT}

The predominance of more or less tolerant species to low oxygen concentrations according to their tolerance ranges, the clusters, and factors distribution, are assessed in this study to characterize the bottom water setting in the GT for the last 6 millennia.

Discerning amongst dysoxic $(2-0.2 \mathrm{ml} / \mathrm{l})$, suboxic $(0.2-$ $0.0 \mathrm{ml} / \mathrm{l})$ or anoxic $(0.0 \mathrm{ml} / \mathrm{l})$ environments (Tyson and Pearson, 1991) throughout the sedimentary sequence considering the relative (and large) tolerance ranges of DO concentrations of the main taxa in core MD02-2521 is complex. Laminations occur intermittently across the sediment core without a clear pattern or trend (Figure 3). A threshold of $0.2 \mathrm{ml} / 1$ could be figured out along the sediment core since laminations remain preserved when DO levels drop under 0.2 ml/1 (Savrda et al., 1984).

From the PCA it is found that most samples are distributed along PC1 (Figure 8b), suggesting that there is one main environmental variable controlling the occurrence of the different taxa. Following the SIMPER analysis (Table 2), samples rich in $E$. sandiegoensis (highly tolerant to low-oxygen concentrations within the OMZ in the GT; see taxonomic notes above) spread over the positive part of the principal component 1 in Figure $8 \mathrm{~b}$. Also, this taxon has the strongest effect (loading: 0.77) on principal component 1 (Supplemental Appendix 5). It appears, therefore, that $E$. sandiegoensis predominates amongst the other seven most abundant species in core MD02-2521. Samples richer in $B$. seminuda (less tolerant to suboxic-anoxic environments; see taxonomic notes above) mixed with similar proportions of $E$. sandiegoensis occupy the negative portion (Figure $8 b$ ). It is, therefore, deducible that the bottom oxygen level is the environmental variable that controls either the distribution and/or preservation of the species along the sedimentary sequence. In accordance with these results, BF assemblages from the Santa Barbara Basin showed no relationship with changes of neither OM fluxes nor sedimentary parameters suggesting that the controlling factor of the benthic fauna is the variation of bottom oxygen levels (Ohkushi et al., 2013). Only the sample (21-21.5 to 650 cal yrs BP; Figure 8 b, in orange) containing an extremely high amount of $B$. tenuata (76.3\%, Table 2, Supplemental Appendix 3) is displaced towards the positive axis of PC2. This taxon can stand anoxia, however, no extraordinary event that could have caused an anoxic event has been reported at this time. Well-preserved laminations are observed at $21-21.5 \mathrm{~cm}$ (Figure 3), yet these laminations don't look different from the rest in the core and no color or textural change is detected. At the present moment, we do not have an explanation for this single event.

On the other hand, relative tolerances can be assessed by focusing on the correlation coefficients (Supplemental Appendix 6) between each taxon and dominance or diversity index. We rely on the basis that periods of high dominance are associated with decreases of oxygen levels where most taxa are not able to stand such conditions, and the opposite should occur in periods of higher oxygenation (e.g. Den Dulk et al., 2000). Following the previous statement, positive correlations to the diversity index are shown for G. nitidula (0.57), Epistominella sp. (0.52), B. seminuda (0.49), E. obesa (0.37), and a weaker coefficient for P. bradyana (0.21). On the contrary, E. sandiegoensis shows a positive correlation with dominance $(0.65)$ as well as $B$. tenuata $(0.37)$ and, with a lower coefficient, $T$. delicata ( 0.28$)$, with corresponding negative correlations to the diversity index (Supplemental Appendix 6). According to the previous facts, and supporting the living fauna data from Tehua campaigns (Table 1, see taxonomic and ecological notes), we find again that $E$. sandiegoensis and T. delicata indicate lower oxygen conditions in the slope of the GT in contrast to G. nitidula, B. seminuda, and Epistominella sp., which appear to be more abundant in periods of better oxygenation.

An interesting observation is the occurrence of samples with no sign of both benthic nor planktonic foraminifera at 5634, 4039, $3818,3593,3282,3030,2717-2591,1578$, and $1110 \mathrm{cal}$ yrs BP (Figures 5 and 6, Supplemental Appendices 3 and 4). These samples were inspected in order to find out more hints for the lack of foraminifera. The distinctive feature of those samples missing benthic and planktonic foraminifera is the presence of (large) fragments of gypsum and/or pyrite (only in two samples). Precipitation of gypsum is caused by sulfide oxidation reactions under low oxygen conditions (Blanchet et al., 2012; Schnitker et al., 1980; Self-Trail and Seefelt, 2005). These reactions may cause the environment to turn more acidic, which can trigger the dissolution of biogenic carbonates (Schnitker et al., 1980). The presence of large fragments of gypsum in samples without foraminifera is, consequently, a likely cause for the dissolution of their tests. Likewise, the presence (although scarcer than gypsum) of pyrite in framboidal form (packed spherical aggregates of pyrite crystals, Wilkin et al., 1996) is also a sign of high levels of anoxia and a chemocline positioned at the water-sediment surface favoring the dissolution of calcite (Tribovillard et al., 2006), which adds another probable cause for the disappearance of benthic and planktonic foraminifera at the above-mentioned levels. Intense dissolution associated with near anoxic conditions is supported by Ontiveros-Cuadras et al. (2019), who found high molybdenum and uranium (redox-sensitive trace elements) where foraminifera were absent. Upwelling and resulting high production rates contribute to fluctuations of carbonate saturation in oxygen-poor habitats that in turn produce changes in foraminiferal calcite (Gibson et al., 2016). It has been proved that in the Eastern Tropical North Pacific (ETNP), seawater $\mathrm{pH}$ decreases after the Tehuano-induced upwelling (e.g. Chapa-Balcorta et al., 2015; Feely et al., 2008; Rixten et al., 2012). Upwelling acidic waters in the GT imply a related reason for the dissolution of carbonates in core MD02-2521 and, definitely, all these factors may be favoring the dissolution of foraminiferal carbonate tests.

\section{Change of bottom-water oceanography at $\sim 2500$ years}

The distribution of the foraminiferal assemblages across the last $\sim 6000$ years determines the distribution of clusters (groups 
of samples with similar foraminiferal composition) across the sediment core pointing to a changing bottom environment oxygenation.

According to the SIMPER analysis, E. sandiegoensis and $B$. seminuda are the two more influential species in core MD022521 (Table 2). Since E. sandiegoensis is one of the less tolerant species to oxygen depletion compared to $B$. seminuda, DO relative fluctuations may be well characterized by overlapping their curves of relative abundance (Figure 5). In general terms, a replacement between maximum and minimum occurrences of both species is found during the interval 5407-2591 cal yrs BP. (Figure 5). Later on, from 2591 cal yrs BP to the top, both curves suffer a detachment observing a notable increasing abundance of E. sandiegoensis in contrast to a decline of $B$. seminuda, thus the previous replacement between both taxa do not exist anymore. The antagonistic behavior of the two species is in turn corroborated by their corresponding opposite values along the principal component 1 axis (Figure 8b, Supplemental Appendix 5). The split-up of the abundance curves and next dominance of E. sandiegoensis suggest a declination of the bottom oxygen conditions in the recent $2591-573$ cal yrs BP.

The rest of the species, still being less influential within the total assemblage (see Table 2), supports the previous finding. The positive correlation between E. sandiegoensis and T. delicata is noticeable in Figure 6 with a similar distribution trend that supports a general decline of bottom water ventilation from $2591 \mathrm{cal}$ yrs BP. On the other hand, G. nitidula, Epistominella sp., as well as $P$. bradyana, and, less perceptibly, E. obesa, are more abundant towards the bottom of the sedimentary sequence (Figure 6) suggesting improved oxygen conditions before $2591 \mathrm{cal}$ yrs BP.

The change of bottom water conditions suggested by our BF is reinforced by a prominent $\delta^{15} \mathrm{~N}$ minimum at around 2700 years BP reported from the sediment core ME 0005A in the GT (Thunell and Kepple, 2002; Figure 5). Intense denitrification around 2500 cal yrs BP by $\delta^{15} \mathrm{~N}$ minima has been found in MD02-2520 (Pichevin et al., 2010), located in the GT, as well as in Ocean Drilling Program (ODP) Site 1242 in the Central American Pacific (Robinson et al., 2009). Causes of denitrification have been attributed to variations in biogeochemical cycles and oceanographic dynamics due to climatic variations such as cold-warm alternations and local changes of upwelling intensity (Pichevin et al., 2010; Robinson et al., 2009; Thunell and Kepple, 2002). If denitrification takes place when DO concentrations fall to values under $0.2 \mathrm{ml} / 1$ (Naqvi and Jayakumar, 2000), the lack of BF from 2717 to 2591 may be probably related to a strong fall of DO and intense denitrification in this area marking a tipping point between 2700 and 2500 years toward diminished oxygenation.

\section{Climatic implications}

The late-Holocene has been generally assumed as a rather climatically stable epoch when comparing it with glacial-interglacial times or previous periods of abrupt climate changes (Dansgaard et al., 1993). However, some authors (e.g. DeMenocal and Bond, 1997; Mayewski et al., 2004) reported climate variability and abrupt changes during the Holocene from globally distributed terrestrial, marine, and ice records which are likely driven by changes of solar irradiance (Denton and Karlen, 1973). In the ETNP, some studies have tried to figure out the climatic and oceanographic mechanisms driving biogeochemical variations in surface and bottom waters during the Quaternary and effects on the seafloor ecosystems (e.g. Ganeshram et al., 2000; Moffitt et al., 2014, 2015; Nameroff et al., 2004; Pichevin et al., 2010; Praetorius et al., 2015; Schmittner et al., 2007). However, only a few studies put attention on the GT, so the drivers of bottom oxygen variations in this area remain unclear. In this section, information on governing climatic and oceanographic processes affecting ventilation in the ETNP and GT will be gathered from previous work, and finally, the most probable scenario for the GT according to our micropaleontological data will be proposed.

Climate drivers in the Eastern Tropical North Pacific. Regionally, the mechanisms governing the climate of the ETNP are reported to be driven by solar irradiance, which promotes atmospheric dynamics at decadal-centennial scales such as the North American Monsoon (NAM) and the migration of the ITCZ (e.g., Choumiline et al., 2019; Poore et al., 2004). So, when there is maximum solar irradiance over the ETNP, such as during summer months, the ITCZ is situated over the GT carrying atmospheric moisture that intensifies the NAM and weakens winds and upwelling, as well as productivity rates (Barron et al., 2012; Haug et al., 2001; Pérez-Cruz, 2013). The opposite happens when the ITCZ migrates to the south over equatorial latitudes (Utida et al., 2019). From a paleontological point of view, studies on both the Atlantic and Pacific sides (e.g., Haug et al., 2001; Pérez-Cruz, 2013; Poore et al., 2004) have reported that the overall position of the ITCZ has experienced a southward migration during the late-Holocene. Low values of titanium from $\sim 2500$ years towards the recent indicates diminished precipitation rates in the Cariaco Basin (ODP Site 1002) related to a southerly movement of the ITCZ (Haug et al., 2001; Figure 5). At the same time, in the Gulf of Mexico (core MD02-2553) the relative abundance of Giroidinoides sacculifer suffers a decline from $\sim 3000$ years related to a relocation of the ITCZ over lower latitudes (Poore et al., 2004; Figure 5). This gradual southward path of the ITCZ would implicate more intense trade-winds over the GT, with consequent intensified upwelling and larger productivity rates that would be well reflected in this study by the decreasing (increasing) trend of foraminiferal diversity (dominance) from 2500 years (Figure 5) and the increase (decrease) of taxa indicative of low (high) oxygen conditions E. sandiegoensis and T. delicata (B. seminuda, G. nitidula, Epistominella sp.; Figure 6). Lower oxygenation is supported by larger organic carbon accumulation rates from sediment core MD02-2520 (Contreras-Rosales, 2008), next to MD02-2521, observed from $3000 \mathrm{cal}$ yrs BP with a substantial increase from 1500 to $500 \mathrm{cal}$ yrs BP (Figure 5).

Oceanographic drivers of bottom-water oxygenation in the Eastern Tropical North Pacific. Variations of export productivity and denitrification can be a reliable indicator of relative changes of bottom oxygen levels in the GT, which in turn might be related to the transitions between cold and warm stages in Greenland. According to Ganeshram et al. (2000), lower denitrification during glacial periods in the ETNP occurred due to low upwelling and low export productivity flux through the OMZ. Accordingly, Dansgaard-Oeschger (D-O) stadials in the North Atlantic are associated with reduced delivery of nutrients to the Pacific and Indian Oceans that reduce productivity in both areas (Schmittner et al., 2007). This is supported by proxy data from Santa Barbara Basin sediments in which enhanced oxygenation associated with increased intermediate-water circulation and lower surface temperatures were found during Atlantic cold D-O phases (Behl and Kennet, 1996). More locally in the GT, it appears that during interstadial periods, subsurface ventilation became poorer, aiding the development of the OMZ and denitrification (Hendy and Pedersen, 2006; Thunell and Kepple, 2002). Similarly, Pichevin et al. (2010) reported the lowest $\delta^{15} \mathrm{~N}$ levels in the GT during D-O stadials and opposite effects during interstadials. Further south, in the Nicaragua Basin, the $\delta^{15} \mathrm{~N}$ record seems to be more related to the northward advection of heavy nitrate produced in Chile and Peru rather than due to local processes (Pichevin et al., 2010), thus reflecting an anti-northern or Southern signal. The authors suggest that bottom water ventilation in the GT might be partially 
affected by this cross-equatorial advection of heavy nitrate from the Southern Hemisphere, likely explaining the offset (a few hundred to a thousand years) between Greenland events and oceanography in the GT, thus showing a combined signal between local/ regional processes from both Hemispheres. However, caution must be exerted since these cross-equatorial water-mass exchange mechanisms seem not to be well understood (Kessler, 2006), and forcing mechanisms during glacial periods may not work in the same way or with the same intensity in the late-Holocene. Nevertheless, this oceanographic response in the ETNP and the GT during glacial/stadials and interglacial/interstadials will be considered later in this study.

In the Holocene, Bond Cycles, with a periodicity of $1470 \pm 500$ years, have been reported as the most prominent manifestations of Holocene climate variability in the North Atlantic (Bond et al., 1997; 2001; Wanner and Bütikofer, 2008). Bond events are defined as ice-rafting discharges into lower latitudes in the North Atlantic Ocean that mark climate fluctuations (Bond et al., 1997; 2001; Wanner and Bütikofer, 2008). Melting of ice at lower latitudes causes the freshening of the ocean surface. As a consequence, NADW is shallower and less dense (Bond and Lotti, 1995; Bond et al., 2001; Lehmann and Keigwin, 1992). In general terms, this newly formed water may take between 900 and 1000 years within the pathway of the Thermohaline Circulation (THC) until it reaches the ETNP, already as North Pacific Intermediate Water (NPIW; Hendy and Kennet, 2003; Primeau, 2004). Further back in time, Atlantic cold periods such as D-O cold phases and Heinrich events were able to cause such changes in the North Pacific after modification of the NADW formation (Alley and Clark, 1999). In this study, the response of BF to climate oscillations seems to follow a cyclic pattern, as evidenced by the diversity indices (Figure 5). The dominance record was decomposed by spectral analysis to reveal the main cyclic periods governing the almost 6 millennia record of sediment core MD02-2521. The most powerful cycle has a frequency of 0.000676 years $^{-1}$, resulting in a period of 1470 years. Due to the similar periodicity of Bond cycles, we suspect that BF of this study might be responding to Bond events, as this periodicity is observable in the time span between two maxima (minima) of the dominance (diversity) record (Figure 5), especially during the last 2500 years.

Last 2500 years. The last 2.5 millennia have been marked by the succession of warm and cold climate phases marked by the Roman Warm Period (RWP; 2500 to $\sim 1700$ yrs BP), Dark Ages Cold Period (DACP; 1700 to $\sim 1400$ yrs BP), Medieval Warm Period (MWP; $\sim 1400$ to $\sim 700 \mathrm{yrs} \mathrm{BP}$ ), and the Little Ice Age (LIA; $\sim 750$ to $\sim 550 \mathrm{yrs} \mathrm{BP}$ ) (e.g., Helama et al., 2017; Lamb, 1965; Ljungqvist, 2010; Mann et al., 2009). Although these events have been considered of global scope, there is a general bias in placing their origin and effects over Europe and North America. In this respect, Neukom et al. (2019) confirm that there is no coherent synchronicity ubiquitously, besides no consensus may exist about their temporal extent (e.g., Helama et al., 2017; Lamb, 1965; Ljungqvist, 2010; Matthews and Briffa, 2005). In this study, the BF populations appear to experience changes synchronously with the previously defined warm-cold transitions of the Late-Holocene (Figure 5). Hence an overall decrease (increase) of diversity (dominance) is observed during the warm epochs such as the RWP and the MWP. The opposite is noticed during the cold DACP, although a change parallel to the LIA is not as evident since our record ends where the LIA is presumably about to start (Figures 5 and 6). Larger amounts of BF and PF per gram of core MD02-2521 are noticeable during the DACP in contrast to the warm periods (Figure 5), which is visible in the planktonic $G$. sacculiffer record from the Gulf of Mexico as well (Poore et al., 2004; Figure 5). Similarly, larger amounts of planktonic foraminifera per gram are found during glacial periods in the GT (Arellano-Torres et al., 2013), as well as in the Santa Barbara Basin, where higher diversity and species number was reported during cooler intervals by Ohkushi et al. (2013). This suggests a consistent effect of climatic variations on benthic habitats along the Eastern Pacific since cold periods may lower sea surface temperatures, promoting mixing of water masses, oxygenation, and absence of upwelling which could be the reason for the occurrence of larger amounts of benthic and planktonic foraminifera and greater diversity (Arellano-Torres et al., 2013; Figure 5). Larger amplitudes in the diversity records during the MWP could reflect the larger variability of precipitation reported by Haug et al. (2001) deducted by larger amplitudes in the titanium record (Figure 5) due to the relative positions of the ITCZ. Moreover, Pichevin et al. (2010) reported maximum denitrification levels in the GT during warm episodes also related to intensified upwelling and lower oxygenation. Since denitrification causes carbonate dissolution, it is reasonable to find a lower abundance of benthic and planktonic foraminifera, as well as lower diversity during the RWP and MWP in this study (Figure 5).

Conclusive remarks on Late-Holocene climate in the GT. Despite Bond cycles were defined from cooling events represented by higher concentrations of ice-rafted debris in the North Atlantic Ocean (Bond et al., 2001), the same millennial-scale variability has been noted in the Pacific side (Southern California) reflected in changes of the position of the thermocline induced by wind, linked to the North Atlantic cooling events (Behl and Kennett, 1996). Cold-warm stages of the Holocene are much less intense in contrast to previous epochs (e.g. Last Glacial Maximum, D-O stadials and interstadials, Heinrich events). For this reason, we suspect that the effect of ice-rafting toward low latitudes during Bond events and shallower reach of NADW may not exert such intense impact in the THC water mass exchange and biogeochemical processes once it arrives at the GT, already converted into NPIW (Hendy and Kennet, 2003; Primeau, 2004). Thus it seems more probable that Greenland climate variations in the late-Holocene have a greater impact in the GT via atmospheric link and this study provides new fossil evidence of millennial variability in the ETNP occurring synchronously as in the North Atlantic, suggesting a climatic connection between the Atlantic and Pacific oceans as it was reported in Pérez-Cruz (2013) as well. On one hand, these connections would be evidenced via atmosphere by a general decrease of ventilation from 2500 years toward the recent due to the southward migration of the ITCZ. On the other hand, this would be a likely explanation of little or no apparent time lag between Greenland and GT as seen during the RWP, DACP, and MWP in core MD02-2521.

Finally, this study may serve as a starting point for future research with a larger array of proxies and tracers at a higher resolution to find out more robust evidences and refine the mechanisms that drive bottom water ventilation in this area.

\section{Conclusion}

The present study provides the first $\sim 6$ millennia reconstruction of bottom-water environmental conditions in the Gulf of Tehuantepec (GT) using sediment core MD02-2521. The distribution of benthic foraminiferal taxa encountered throughout the past 6000 years responds to changing levels of bottom dissolved oxygen (DO) within the Oxygen Minimum Zone. After reassessing the taxonomy and ecology of the main taxa of MD02-2521, two assemblages, defined by a Q-mode cluster analysis, determine the main oxygenation changes across the sedimentary sequence as follows. Epistominella sandiegoensis, T. delicata, and B. tenuata, indicators of low oxygenation in the GT, experience abundance increase from $\sim 2500$ years in contrast to the decreasing trends of 
the higher oxygen level indicators B. seminuda, G. nitidula, Epistominella sp., E. obesa, and P. bradyana. A Principal Component Analysis confirms the distribution of these two assemblages along the principal component 1 , representing the DO level as the main environmental factor to which foraminifera respond. The change of oceanographic conditions at 2500 years is likely linked to an intense denitrification event and the beginning of southward migration of the Intertropical Convergence Zone in the late-Holocene. In addition, sediment core layers without benthic and planktonic foraminifera contain a larger amount of gypsum and, in some cases, framboidal pyrite, revealing periods of intense suboxia and carbonate dissolution along the last 6000 years.

The dominance index shows cyclicities of 1470 years that might be related to Bond Cycles, defined as ice-rafted events in the North Atlantic Ocean. Additionally, lower diversity, higher dominance, and a larger amount of foraminifera are found during warm periods (Roman Warm Period and Medieval Warm Period), while the opposite happens during the cold epochs (Dark Ages Cold Period and Little Ice Age). Benthic foraminiferal assemblages of sediment core MD02-2521 provide a first approach of likely climatic and oceanographic mechanisms prevailing in the GT during the late-Holocene, as well as evidence of climatic connections between the Atlantic and Pacific Oceans.

\section{Acknowledgements}

A. Rodríguez-Ramírez, F. Ponce, H.M. Alexander (ICML), and M. Cabral (Adobe Inc.) are acknowledged for technical and graphical support. L.E. Gómez-Lizárraga provided technical aid with the S.E.M. images at the ICML. Thanks to E. Tappa for providing data. Support for field sampling was provided by UNAM through oceanic campaigns Tehua II, VIII, X, and XII; scientists and crew of the RVs El Puma and the Marion Dufresne (IMAGES VII/MD126 MONA campaign) are acknowledged for collecting the data. Thanks to X.A. Nava (ICML) for constructive discussions and D. Peralta for her labor on the samples. Two reviewers are acknowledged for their valuable comments and suggestions on the manuscript.

\section{Funding}

The author(s) disclosed receipt of the following financial support for the research, authorship, and/or publication of this article: The Dirección General de Asuntos de Personal Académico and the Coordinación Técnica de la Investigación Científica of the Universidad Nacional Autónoma de México are acknowledged for the Postdoctoral grant record Nr. [CJIC/CTIC/0995/2018] approved to the corresponding author of this study. The ICML-UNAM provided the resources to MLMC for the analysis required.

\section{ORCID iD}

Ángela García-Gallardo (iD https://orcid.org/0000-0001-8802 $-7512$

\section{Supplemental material}

Supplemental material for this article is available online.

\section{References}

Alley RB and Clark PU (1999) The deglaciation of the Northern Heisphere: A Global Perspective. Annual Review of Earth Planet Sciences 27: 149-182.

Altenbach AV, Pflaumann U, Schiebel R et al. (1999) Scaling percentages and distributional patterns of $\mathrm{BF}$ with flux rates of organic carbon. Journal of Foraminiferal Research 29 (3): $173-185$.

Antoine D, André JM and Morel A (1996) Oceanic primary production 2. Estimation at global scale from satellite (coastal zone color scanner) chlorophyll. Global Biochemical Cycles 10 (1): 57-69.

Arellano-Torres E, Machain-Castillo ML, Contreras-Rosales LA et al. (2013) Foraminiferal faunal evidence for Glacial-Interglacial variations in the ocean circulation and the upwelling of the Gulf of Tehuantepec (Mexico). Marine Micropaleontology 100: 52-66.

Balestra B, Quintana Krupinski NB, Erohina T et al. (2018) Bottomwater oxygenation and environmental change in Santa Monica Basin, Southern California during the last 23 kyr. Palaeogeography, Palaeoclimatology, Palaeoecology 490: 17-37.

Bandy OL (1961) Distribution of foraminifera, radiolarian and diatoms in sediments of the Gulf of California. Micropaleontology 7: 1-26.

Barron JA, Metcalfe SE and Addison JA (2012) Response of the North American monsoon to regional changes in ocean surface temperature. Paleoceanography 27: PA3206.

Beaufort L (2002) IMAGES VIII MONA Cruise Report, Institut Polaire Francais Paul-Émile Victor (IPEV), les rapports de campagnes à la mer. PANGAEA 452. http://www.imagespages.org/ftp/pub/MONA/MONA_cruise_report.pdf.

Behl RJ and Kennett JP (1996) Brief interstadial events in the Santa Barbara basin, NE Pacific, during the past 60 kyr. Nature 379: 243-246.

Berger R, Taylor RE and Libby WF (1966) Radiocarbon content of marine shells from the California and Mexican west coast. Science 153 (3738): 864-866.

Bernhard JM and Reimers CE (1991) Benthic foraminiferal population fluctuations related to anoxia: Santa Barbara Basin. Biogeochemistry 15: 127-149.

Bernhard JM and Sen Gupta BK (1999) Foraminifera of oxygendepleted environments. In: Sen Gupta BK (ed.) Modern Foraminifera. Dordrecht: Kluver Academic Publisher, pp.37-55.

Bernhard JM, Sen Gupta BK and Borne PF (1997) BF proxy to estimate dysoxic bottom-water oxygen concentrations. Santa Barbara Basin, US Pacific continental margin. Journal of Foraminiferal Research 27: 301-310.

Blake GH (1976) The distribution of BF in the outer borderland and its relationship to Pleistocene facies. Master thesis. University of South Carolina. Los Angeles.

Blanchet CL, Kasten S, Vidal L et al. (2012) Influence of diagenesis on the isotopic composition of biogenic carbonates from the Gulf of Tehuantepec oxygen minimum zone. Geochemistry, Geophysics, Geosystems 113 (4): Q04003.

Bond G, Kromer B, Beer J et al. (2001) Persistent solar influence on North Atlantic climate during the Holocene. Science 278: $1257-1266$.

Bond GC and Lotti R (1995) Iceberg discharges into the North Atlantic on millennial timescales during the last deglaciation. Science 267: 1005-1010.

Bond G, Showers W, Cheseby M et al. (1997) A pervasive millennial-scale cycle in the North Atlantic Holocene and glacial climates. Science 294: 2130-2136.

Brady HE (1884) Report on the Foraminifera Dredged by H.M.S. Challenger, During the Years 1873-1876. Report on the Challenger Expedition. London, England, 1884. Zoology pt. 22, vol. 9, p. 696.

Cannariato KG, Kennett JP and Behl RJ (1999) Biotic response to late Quaternary rapid climate switches in Santa Barbara Basin: Ecological and evolutionary implications. Geology 27(1): 63-66.

Carranza-Edwards A, Morales de la Garza E and Rosales Hoz L (1998) Tectonics, sedimentology and geochemistry. In: Tapia-Garcia M (ed.) El Golfo de Tehuantepec: el ecosistema y sus recursos. México: Universidad Autónoma Metropolitana-Iztapalapa, pp.1-11. 
Chapa-Balcorta C, Hernandez-Ayon JM, Durazo R et al. (2015) Influence of post-Tehuano oceanographic processes in the dynamics of the $\mathrm{CO}_{2}$ system in the Gulf of Tehuantepec, Mexico. Journal of Geophysycal Research Oceans 120: 7752-7770.

Choumiline K, Pérez-Cruz L, Gray AB et al. (2019) Scenarios of deoxygenation of the eastern tropical north pacific during the past millennium as a window into the future of oxygen minimum zones. Frontiers in Earth Science 7: 237.

Clarke AJ (1988) Inertial wind path and sea surface temperature patterns near the Gulf of Tehuantepec, Mexico and Gulf of Papagayo. Journal of Geophysical Research 93: 5491-5501.

Clarke KR (1993) Non-parametric multivariate analyses of changes in community structure. Australian Journal of Ecology 18 (1): 117-143.

Cline JD and Richards FA (1972) Oxygen deficient conditions and nitrate reduction in the Eastern Tropical North Pacific Ocean. Limnology and Oceanography V 17 (6): 885-900.

Contreras-Rosales LA (2008) Reconstrucción Paleoceanográfica del fenómeno de surgencia en el Golfo de Tehuantepec durante los estadios isotópicos 1 a 3 (Cuaternario tardío) basada en el registro sedimentario de foraminíferos planktónicos. Tesis de licenciatura. Universidad Nacional Autónoma de México.

Cushman JA and McCulloch I (1942) Some Virgulininae in the collections of the Allan Hancock foundation. Allan Hancock Pacific expeditions 6(4): 179-230.

Dansgaard W, Johnsen SJ, Clausen HB et al. (1993) Evidence for general instability of past climate from a $250-\mathrm{kyr}$ ice core record. Nature 364: 218-220.

Davies MH, Mix AC, Stoner JS et al. (2011) The deglacial transition on the SE Alaskan Margin: Meltwater input, sea level rise, marine productivity, and sedimentary anoxia. Paleoceanography 26: PA2223.

DeMenocal P and Bond G (1997) Holocene climate less stable than previously thought. Eos 78 (41): 447-454.

Den Dulk M, Reichart GJ, Heyst SV et al. (2000) BF as proxies of organic matter flux and bottom water oxygenation? A case history from the northern Arabian Sea. Palaeogeography, Palaeoclimatology, Palaeoecology 161: 337-359.

Denton GH and Karlén W (1973) Holocene climatic variationsTheir pattern and possible cause. Quaternary Research 3: $155-205$.

Douglas RG and Heitman HL (1979) Slope and basin BF of the California borderland. In: Doyle LJ and Pikey OH (eds) Geology of Continental Slopes. Broken Arrow, OK: SEPM Special Publication, pp.231-246.

Feely RA, Sabine CL, Hernandez-Ayon JM et al. (2008) Evidence for upwelling of corrosive "acidified" water onto the continental shelf. Science 320: 1490-1492.

Fiedler PC and Lavín MF (2017) Oceanographic conditions of the eastern tropical pacific. In: Glynn PW et al. (eds) Coral Reefs of the Eastern Tropical Pacific, Coral Reefs of the World 8. Dordrecht: Springer Netherlands, pp.59-83.

Ganeshram RS, Pedersen TH, Calvert SE et al. (2000) Glacialinterglacial variability in denitrification in the world's oceans: Causes and consequences. Paleoceanography 15 (4): 361-376.

Gibson KA, Thunell RC, Machain-Castillo ML et al. (2016) Evaluating controls on planktonic foraminiferal geochemistry in the Eastern Tropical North Pacific. Earth and Planetary Science Letters 45: 90-103.

Golik A and Phleger FB (1977) BF from the Gulf of Panama. Journal of Foraminiferal Research 7: 88-100.

Gooday AJ (2003) BF (protista) as tools in deep-water palaeoceanography: Environmental influences on faunal characteristics. In: Southward AJ, Tyler PA, Young CM et al. (eds) Advances in Marine Biology. London: Academic Press, pp. $1-90$.
Gooday AJ and Rathburn AE (1999) Temporal variability in living deep-sea BF: a review. Earth-Science Reviews 46: 187-212.

Hammer $\varnothing$ and Harper DAT (2006) Paleontological Data analysis. Oxford: Blackwell Publishing Ltd.

Hammer Ø, Harper DAT and Ryan PD (2001) Past: palaeontological statistics software package for education and data analysis. Palaeontologica Electronica 4: 9.

Harman RA (1964) Distribution of foraminifera in Santa Barbara Basin, California. Micropaleontology 10: 81-96.

Haug GH, Hughen KA, Peterson LC et al. (2001) Southward migration of the Intertropical Convergence Zone through the Holocene. Science 293: 1304-1308.

Helama S, Jones PD and Briffa KR (2017) Dark ages cold period: A literature review and directions for future research. The Holocene 27 (10): 1600-1606.

Hendy IL and Kennet JP (2003) Tropical forcing of North Pacific intermediate water distribution during Late Quaternary rapid climate change? Quaternary Science Reviews 22: 673-689.

Hendy IL and Pedersen TF (2006) Oxygen minimum zone expansion in the eastern tropical North Pacific during deglaciation. Geophysical Research Letters 33: L20602.

Hermelin JOR (1991) The benthic foraminiferal faunas of sites 725, 726, and 728 (Oman Margin, Northwestern Arabian Sea). Proceedings of the Ocean Drilling Program, Scientific Results 117: 55-87.

Hurd WE (1929) Northers of the Gulf of Tehuantepec. Monthly Weather Review 57(5): 192-194.

Jorissen FJ, De Stigter HC and Widmark JGV (1995) A conceptual model explaining BF microhabitats. Marine Micropaleontology 26 (1-4): 3-15.

Kamykowski D and Zentara SJ (1990) Hypoxia in the world ocean as recorded in the historical data set. Deep-Sea Research 37 (12): 1861-1874.

Kessler WS (2006) The circulation of the eastern tropical Pacific: A review. Progress in Oceanography 69: 181-217.

Lamb HH (1965) The early medieval warm epoch and its sequel. Palaeogeography, Palaeoclimatology, Palaeoecology 1: 13-37.

Lavín MF, Robles JM, Argote ML et al. (1992) Física del Golfo de Tehuantepec. Ciencia y Desarrollo 18(103): 97-107.

Lehmann SJ and Keigwin LD (1992) Sudden changes in the North Atlantic circulation during the last deglaciation. Nature 356: 757-62.

Ljungqvist FC (2010) A new reconstruction of temperature variability in the extra-tropical Northern Hemisphere during the last two millennia. Geografiska Annaler: Series A, Physical Geography 92: 339-351.

Lobegeier M and Sen Gupta BK (2008) Foraminifera of Hydrocarbon seeps, Gulf of Mexico. Journal of Foraminiferal Research 38 (2): 93-116.

McGann M and Conrad JE (2018) Faunal and stable isotopic analyses of BF from the Southeast Seep on Kimki Ridge offshore southern California, USA. Deep Sea Research Part II 150: 92-117.

Machain-Castillo ML, Ruiz-Fernández AC, Gracia A et al. (2019) Natural and anthropogenic oil impacts on benthic foraminifera in the southern Gulf of Mexico. Marine Environmental Research 149: 111-125.

Mann ME, Zhang Z, Rutherford S et al. (2009) Global signatures and dynamical origins of the little ice age and medieval climate anomaly. Science 326 (5957): 1256-1260.

Matthews JA and Briffa KR (2005) The 'Little Ice Age': Reevaluation of an evolving concept. Geografiska Annaler 87A: $17-36$.

Mayewski PA, Rohling EE, Stager JC et al. (2004) Holocene climate variability. Quaternary Research 62: 243-255.

Metcalfe SE, Barron JA and Davies SJ (2015) The Holocene history of the North American Monsoon: 'known knowns' and 
'known unknowns' in understanding its spatial and temporal complexity. Quaternary Science Reviews 120: 1-27.

Meyers S, Malinverno A, Hinnov L et al. (2019) Asthrochron: a computational tool for astrochronology. $R$ package version 0.9 .

Moffitt SE, Hill TM, Ohkushi K et al. (2014) Vertical oxygen minimum zone oscillations since $20 \mathrm{ka}$ in Santa Barbara Basin: A benthic foraminiferal community perspective. Paleoceanography 29: 44-57.

Moffitt SE, Hill TM, Roopnarine PD et al. (2015) Response of seafloor ecosystems to abrupt global climate change. Proceedings of the National Academy of Sciences 112: 4684-4689.

Molina-Cruz A and Martinez-López M (1994) Oceanography of the Gulf of Tehuantepec, Mexico, indicated by Radiolaria remains. Palaeogeography, Palaeoclimatology, Palaeoecology 110: 179-195.

Murray JW (2006) Ecology and applications of Benthic Foraminifera. Cambridge: Cambridge University Press.

Nameroff TJ, Calvert SE and Murray JW (2004) Glacial-interglacial variability in the eastern tropical North Pacific oxygen minimum zone recorded by redox-sensitive trace metals. Paleoceanography 19: PA1010.

Naqvi SWA and Jayakumar DA (2000) Ocean biogeochemistry and atmospheric composition: Significance of the Arabian Sea. Current Science 78: 289-299.

Neukom R, Stelger N, Gómez-Navarro JJ et al. (2019) No evidence for globally coherent warm and cold periods over the preindustrial Common Era. Nature 571: 550-554.

Ohkushi K, Kennett JP, Zeleski CM et al. (2013) Quantified intermediate water oxygenation history of the NE Pacific: A new BF record from Santa Barbara basin. Paleoceanography 28: 453-467.

Ontiveros-Cuadras JF, Thunell R, Ruiz-Fernández AC et al. (2019) Centennial OMZ changes in the NW Mexican Margin from geochemical and foraminiferal sedimentary records. Continental Shelf Research 176: 64-75.

Ortiz JD, O'Connell SE, DelViscio J et al. (2004) Enhanced marine productivity off western North America during warm climate intervals of the past 52 k.y. Geology 32(6): 521-524.

Páez M, Zúñiga O, Valdés J et al. (2001) Foraminíferos bentónicos recientes en sedimentos micróxicos de la bahía Mejillones del Sur $\left(23^{\circ} \mathrm{S}\right)$, Chile. Revista de Biología Marina y Oceanografia 36 (2): 129-139.

Pérez-Cruz L (2013) Hydrological changes and paleoproductivity in the Gulf of California during middle and late-Holocene and their relationship with ITCZ and North American Monsoon variability. Quaternary Research 79: 138-151.

Pérez-Cruz L and Machain-Castillo ML (1990) BF of the oxygen minimum zone, continental shelf of the Gulf of Tehuantepec, Mexico. Journal of Foraminiferal Research 20 (4): 312-325.

Phleger FB (1954) Ecology of foraminifera and associated microorganisms from Mississippi Sound and environs. Bulletin of the American Association of Petroleum Geologists 38: 584647.

Phleger FB and Soutar A (1973) Production of BF in three east Pacific oxygen minima. Micropaleontology 19: 110-115.

Pichevin LE, Ganeshram RS, Francavilla S et al. (2010) Interhemispheric leakage of isotopically heavy nitrate in the eastern tropical Pacific during the last glacial period. Paleoceanography 25: PA1204.

Poore RZ, Quinn TM and Verardo S (2004) Century-scale movement of the Atlantic Intertropical Convergence Zone linked to solar variability. Geophysical Research Letters 31: L12214.

Praetorius SK, Mix AC, Walczak MH et al. (2015) North Pacific deglacial hypoxic events linked to abrupt ocean warming. Nature 527: 362-366.
Primeau F (2004) Characterizing Transport between the Surface Mixed Layer and the Ocean Interior with a Forward and Adjoint Global Ocean Transport Model. Journal of Physical Oceanography 35 (4): 545-564.

Quintero PJ and Gardner JV (1987) Benthic Foraminifera on the continental shelf and upper slope. Russian River, northern California. Journal of Foraminiferal Research 17: $132-152$.

Reimer PJ, Bard E, Bayliss A et al. (2013) IntCal13 and Marine13 Radiocarbon Age Calibration Curves 0-50,000 Years cal BP. Radiocarbon 55 (4):1869-1887.

Rixten T, Jiménez C and Cortés J (2012) Impact of upwelling events on the sea water carbonate chemistry and dissolved oxygen concentration in the Gulf of Papagayo (Culebra Bay), Costa Rica: Implications for coral reefs. Revista de Biología Tropical (Int. J. Trop. Biol. ISSN-0034-7744) 60 (Suppl. 2): 187-195.

Robinson RS, Martínez P, Pena LD et al. (2009) Nitrogen isotopic evidence for deglacial changes in nutrient supply in the Eastern equatorial Pacific. Paleoceanography 24: PA4213.

Romero-Centeno R, Zavala-Hidalgo J, Gallegos A et al. (2003) Isthmus of Tehuantepec wind climatology and ENSO signal. Journal of Climate 16 (15): 2628-2639.

Ruiz-Fernández AC, Frignani M, Hillaire-Marcel C et al. (2009) Trace Metals $(\mathrm{Cd}, \mathrm{Cu}, \mathrm{Hg}$, and $\mathrm{Pb})$ accumulation recorded in the intertidal mudflat sediments of three coastal lagoons in the Gulf of California, Mexico. Estuary and Coasts 32: 551-564.

Ruiz-Fernández AC, Páez-Osuna F, Machain-Castillo ML et al. (2004) ${ }^{210} \mathrm{~Pb}$ geochronology and trace metal fluxes $(\mathrm{Cd}, \mathrm{Cu}$ and $\mathrm{Pb}$ ) in the Gulf of Tehuantepec, South Pacific of Mexico. Journal of Environmental Radioactivity 76: 161-175.

Sarmiento JL, Herbert TD and Toggweiler JR (1988) Causes of anoxia in the world ocean. Global Geochemical Cycles 2: 115-128.

Savrda CE, Bottjer DJ and Gorsline DS (1984) Development of a comprehensive oxygen-deficient marine biofacies model: evidence from Santa Monica, San Pedro and Santa Barbara Basins, California Continental Borderland. American Association of Petroleum Geologists 68: 1179-1192.

Schmittner A, Galbraith ED, Hostetler SW et al. (2007) Large fluctuations of dissolved oxygen in the Indian and Pacific oceans during Dansgaard-Oeschger oscillations caused by variations of North Atlantic Deep Water subduction. Paleoceanography 22: PA3207.

Schneider T, Bischoff T and Haug GH (2014) Migrations and dynamics of the intertropical convergence zone. Nature 513: 45-53.

Schnitker D, Mayer LM and Norton S (1980) Loss of calcareous microfossils from sediments through gypsum formation. Marine Geology 36: M35-M44.

Self-Trail JM and Seefelt EL (2005) Rapid dissolution of calcareous nannofossils: A case study from freshly cored sediments of the South-Eastern Atlantic coastal plain. Journal of Nannoplankton Research 27: 149-157.

Sen Gupta BK, Lobegeier MK and Smith LE (2009) Foraminiferal Communities of Bathyal Hydrocarbon Seeps, Northern Gulf of Mexico: A Taxonomic, Ecologic, and Geologic Study. New Orleans, LA: U.S. Department of the Interior, Minerals Management Service Gulf of Mexico OCS Region. OCS Study MMS 2009-013, p. 385.

Sen Gupta BK and Machain-Castillo ML (1993) BF in oxygenpoor habitats. Marine Micropaleontology 20 (3-4): 183-201.

Shibahara A, Ohkushi KI, Kennett JP et al. (2007) Late Quaternary changes in intermediate water oxygenation and oxygen minimum zone, northern Japan: A benthic foraminiferal perspective. Paleoceanography 22: PA3213.

Smith PB (1963) Recent Foraminifera off Central America, Quantitative and qualitative study of the family Bolivinidae. U.S. Geological Survey Proffesional Paper 429: 39. 
Smith PB (1964) Recent foraminifera off Central America, ecology of benthonic species. U.S. Geological Survey Proffesional Paper 429-B: 59.

Staines-Urías F, González-Yajimovich O and Beaufort L (2015) Reconstruction of past climate variability and ENSO-like fluctuations in the southern Gulf of California (Alfonso Basin) since the last glacial maximum. Quaternary Research 83: 488-501.

Stuiver M, Reiner PJ and Reiner RW (2017) Calib. 7.1. Available at: http://calib.org. (accessed 25 October 2017).

Tapia García M (ed.) (1998) El Golfo de Tehuantepec: el ecosistema y sus recursos. México: Universidad Autónoma Metropolitana-Iztapalapa, p. 239.

Thunell RC and Kepple AB (2002) Glacial-Holocene $\delta^{15} \mathrm{~N}$ record from the Gulf of Tehuantepec, Mexico: Implications for denitrification in the eastern equatorial Pacific and changes in amosferic $\mathrm{N}_{2} \mathrm{O}$. Global Biogeochemical Cycles 18: GB1001.

Tribovillard N, Algeo TJ, Lyons T et al. (2006) Trace metals as paleoredox and paleoproductivity proxies: An update. Chemical Geology 232: 12-32.

Tsuchiya M and Talley LD (1998) A Pacific hydrographic section at $88 \mathrm{~W}$ : water-property distribution. Journal of Geophysical Research-Oceans 103: 12,899-12,918.

Tyson RV and Pearson TH (1991) Modern and ancient continental shelf anoxia: an overview. In: Tyson RV and Pearson TH (eds) Modern and Ancient Continental Shelf Anoxia. London:
Geological Sociey of London Special Publication, vol. 58, pp.1-24.

Uchio T (1960) Ecology of Living Benthonic Foraminifera from the San Diego, California, Area. Ithaca, New York: Cushman Foundation Foraminiferal Research Special Publication, 3, p. 68.

Utida G, Cruz FW, Etourneau J et al. (2019) Tropical South Atlantic influence on Northeastern Brazil precipitation and ITCZ displacement during the past 2300 years. Scientific Reports 9: 1698.

Vásquez-Bedoya LF, Radi T, Ruiz-Fernández AC et al. (2008) Organic-walled dinoflagellate cysts and BF in coastal sediments of the last century from the Gulf of Tehuantepec, South Pacific Coast of Mexico. Marine Micropaleontology 68: 49-65.

Wanner H and Bütikofer J (2008) Holocene Bond Cycles: real or imaginary? Geografie 113: 338-350.

Wignall PB and Myers KJ (1988) Interpreting benthic oxygen levels in mudrocks: A new approach. Geology 16: 452-455.

Wilkin RT, Barnes HL and Brantley SL (1996) The size distribution of framboidal pyrite in modern sediments: An indicator of redox conditions. Geochimica et Cosmochimica Acta 60: 3897-3912.

Wyrtki K (1966) Oceanography of the Eastern Equatorial Pacific Ocean. Oceanography and Marine Biology-An Annual Review 4: 33-68. 